\title{
ENVIRONMENTAL
} RESTORATION

PROGRAM

\section{HAZWOPER Project Documents for Demolition of the Waste Evaporator Facility, Building 3506, at Oak Ridge National Laboratory, Oak Ridge, Tennessee}

This dociment has been approved for release to the public by the ORNL. Tectution

Information Oficer. Date: $9 / 26 / 96$

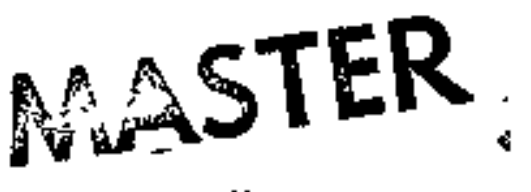

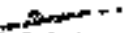
DISTRIBUTHON OF THIS DOCLMENT IS UARIMITIS

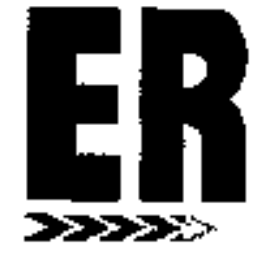




\section{Alied Technology Graup, Inc.}

contriturted to the preparation of this docament and should not be considered an eligible contractor for its review.

This report hes beer reppodiced direstiy from the best availatile copy.

Availeble to DOE and DOE contractors from the Otilce of Sviendific and Technical Information, P.O. Box 62, Odk Ridge, TN 37831; prices available from 423-576-8401 (fax 423-576-2865).

Availeble to the publio ficon the National Teckrical Infonmation Service, U.S.

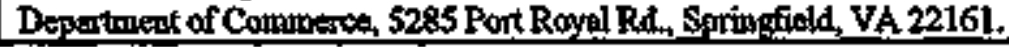


March 29,1996

Mr. M. R. Jugan

Environmental Restoration Division

Department of Energy, Oak Ridge Operations

Post Office Box 2001

Oak Ridge, TN 37831

Dear Mr. Jugan:

HAZWOPER Project Docmments for the Demolition of Waste Evaporator Facility, Building 3506, at Oak Ridge National Laboratory, Oak Ridge, Tennessee (ORNL/ER-347)

The Environmental Restoration Program is pleased to transmit your copy of the subject plan. This document is comprised of the Health and Safety Plan and Project Work Plan which are used by Allied Techsology Group in the performance of demolition activities at the Waste Evaporator Facility (WEF).

Transmittal of this docunsent satisfles one of the delivetables stipulated in the WEF Project Plan (Task Order Proposal).

Please contact me at 576.5557, if you have any questions.

Sincerely,

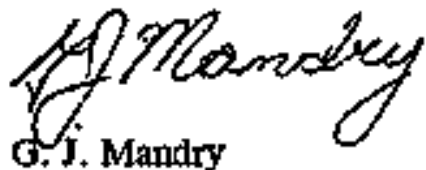

WEF Project Manager

cc: D.G. Cope

G.R. Hudson, DOE-ORO

ER DMC - RC 

Energy Systems Environmental Restoration Program

HAZWOPER Project Document for Deanolition of the Waste Evaporator Facility, Building 3506, at Oak Ridge National Laboratory, Oak Ridge, Tennessee

Date Issued-March 1996

\author{
Prepared by \\ Allied Technology Group, Inc. \\ Oalk Ridge, Tennessee 37830 \\ under subcontract 18X-KEP03V \\ Prepared for the \\ U.S. Department of Enctgy \\ Office of Environmentad Management \\ under budget and reporting code EW 20 \\ Environmental Management Activities at the \\ OAK RIDGE NATIONAL LABORATORY, \\ Oak Rjdge, Tasses 37831-8169 \\ managed by \\ LOCKHEED MARTIN ENERGY SYSTEMS, INC. \\ for the \\ U.S. Department of Energy \\ under contract DE-AC05-\$40R21400
}





\section{PREFACE}

This document, HAZWOPER Project Documents for Demolition of the Faste Evaporator Facility, Bullding 3506, at Oak Ridge National Laboratory, Oak Ridge. Tennessee was prepared to ensure that activities associated with the demolition of the Waste Evaporator Facility, Building 3506, have undergone a hazard ovaluation process, that proper bealth and safety considerations for the workers and the environment have been implemented and that compliance with the Occupational Safety and Health Act of 1970, Title 29, Code of Federal Regutations, 1910.120 has been procured. This document describes the work processes and tho healsh and safety procectures to be utilized during the course of the subject activity. This work was performed under Work Breakdown Structure 1.4.12.6.2.01.12.05, Activity Dath Shect 3701, "Oak Ridge National Laboratory Decontamination and Decommissioning
Program."

\section{DISCLAIMER}

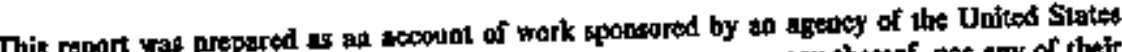

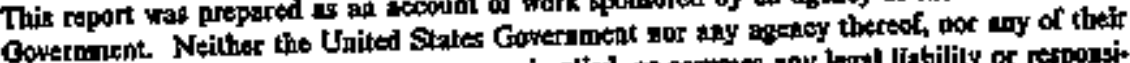

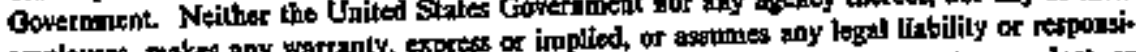

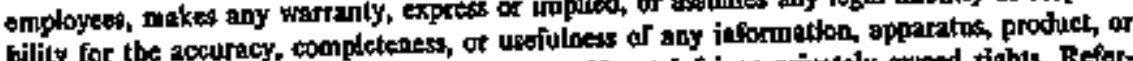

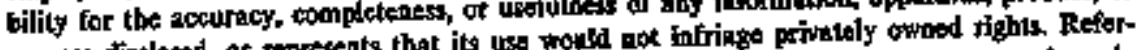

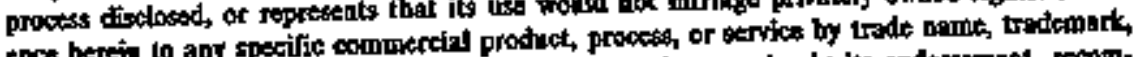

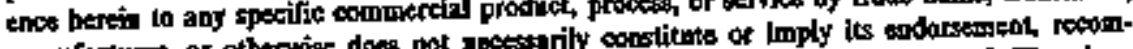

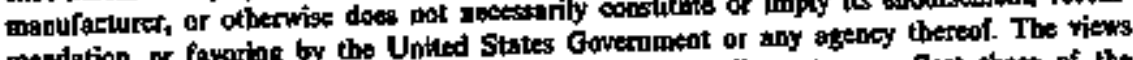
merdation, of faworiag by the Unted Stales Gox nexsersily state or reflect those of the and opinfous of athors expresed hercia do are 



\section{CONTENTS}

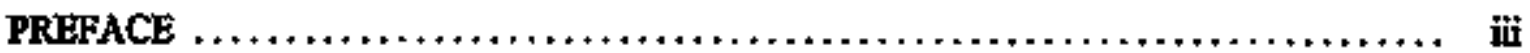

ABBREVIATIONS $\ldots \ldots \ldots \ldots \ldots \ldots \ldots \ldots \ldots \ldots \ldots \ldots \ldots \ldots \ldots \ldots \ldots, \ldots \ldots \ldots, \ldots \ldots$

EXECUTIVE SUMMARY $\ldots \ldots \ldots \ldots \ldots \ldots \ldots \ldots \ldots \ldots \ldots \ldots \ldots \ldots+\ldots \ldots \ldots \ldots+\ldots$, ix

Part I. PROJECT WORK PLAN FOR DEMOLITION AND PARTIAL REMEDIATION OF THE WASTE EVAPORATOR FACLITY, BUILDING 3506, AT OAK RIDGE NATIONAL LABORATORY, OAK RIDGE, TENNESSEE ........ I-I

Part II. PROJECT HEALTH AND SAFETY PLAN FOR DEMOLITON AND PARTIAL REMEDIATION OF THE WASTE EVAPORATOR FACILITY, BUILDING 3506, AT OAK RIDGE NATIONAL LABORATORY, OAK RIDGE, TENNESSEE . . . . . . . . II-I

REFERFNCES 



\section{ABBREVIATIONS}

ACM

ACRM

ALARA

ANSI

ASME

ASTM

ATO

ChR

DAC

DOE

Energy Systems

HAZWOPER

$\mathrm{Hg}$

HP

HPC

IIEPA

III

LLLW

LSS

NRC

ORNL.

OSHA

PAM

PCB

PEL

PIC

PPE

RCRA

RP

RSO

RWP

SHEST

SWSA

TCLP

TLD

TSCA

WEF asbestos containing material

asbestos containing roofing material

as low as reasonably achievable

American Nationsl Standards Institute

Averican Society of Mechanical Engineers

American Society for Testing and Materials

Allied Technology Gtoup

Code of Federal Regulattons

derived air concentration

U.S. Department of Energy

Lockheed Martin Eneryy Systems

hazardous waste operations and emergency response

mercury

Health Pbysics

HAZWOPER Program Coordinater

high efficiency particulate air

Industrial Hysienist

liquid bow level waste

Lisboratory Shift Superintendent

U.S. Nuclear Regulatory Commission

Oak Ridge National Laboratory

Occupational Safety and Health Act of 1970

personnel air montitor

polychlorinated biphenyl

permissible exposure limit

pocket ionization chamber

personal protective equipment

Resource Conservation and Recovery Act of 1976

Radiation Protection

Radiation Safety Officer

Radiation Work Permit

Safety and Health Evaluation and Support Team

Solid Waste Storage Area

Toxicity Characteristic Leaching Procedure

thermoluminescent tosimetr

Toxic Substance Control Act

Waste Evaporator Facility 


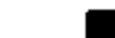




\section{EXECUTIVE SUMMARY}

This document, HAZWOPER Project Documents for Demolition of the Waste Evoporotor Faclify, Buflding 3506, at Oak RJdge National Laboratary, Oak Ridge. Tennessee has been detelopod by Allied Technology Group (ATG) in support of the Waste Evaporator Facility (WEF) demolition projoct and contains the Project Work Plan and the Project Fealth and Safery Plan for demolition and partial renediation actions by ATG at the Waste Evajporator Facility, Building 3506. Various activities will be conducted during the cosrse of demolition, and this plan provides details on the work steps involved, the identification of hazards, and the bealth and safety practices necessary to mitigate these hazards.

The objective of this document is to develop an approach for implementing demolitian activities at the WEF. This approsch is based on prior site characterization infonmation and takes into account all of the known hazards at this facility. The Project Work Plan provides instnuctions and requirements for identified work steps that will be utilized during the performance of demolition, while the Health and Sefety Plan addiesses the radiological, hazardous material exposare, and industrial safety concens that will be encomtered.

This document was prepared by ATG, the demolition subcontractor, and complies with the requirements established by the Ocelpational Safety and Health Act of 1970 , Title 29, Cade of Federal Regulations, 1910.120 for conducting hazardous waste operations and energency response. Adherence to this docament will provide assurance that tasks will be performed safely, efirciently, and costeffectively with appropriate protection of the environment and the health and safely of workers and the general public. 



\section{Part I.}

Project Work Plan for Demolition and Partial Remediation of the Waste Evaporator Facility, Building 3506, at Oak Ridge National Laboratory, Oak Ridge, Tennessee 


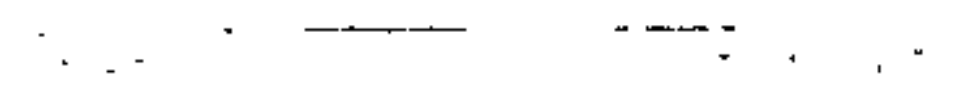


APPROVALS

Part I.

Project Work Plan for Demolition and Partial Remediation of the Waste Evaporator Facility, Building 3506, at Oak Ridge National Laboratory, Oak Ridge, Tennessee
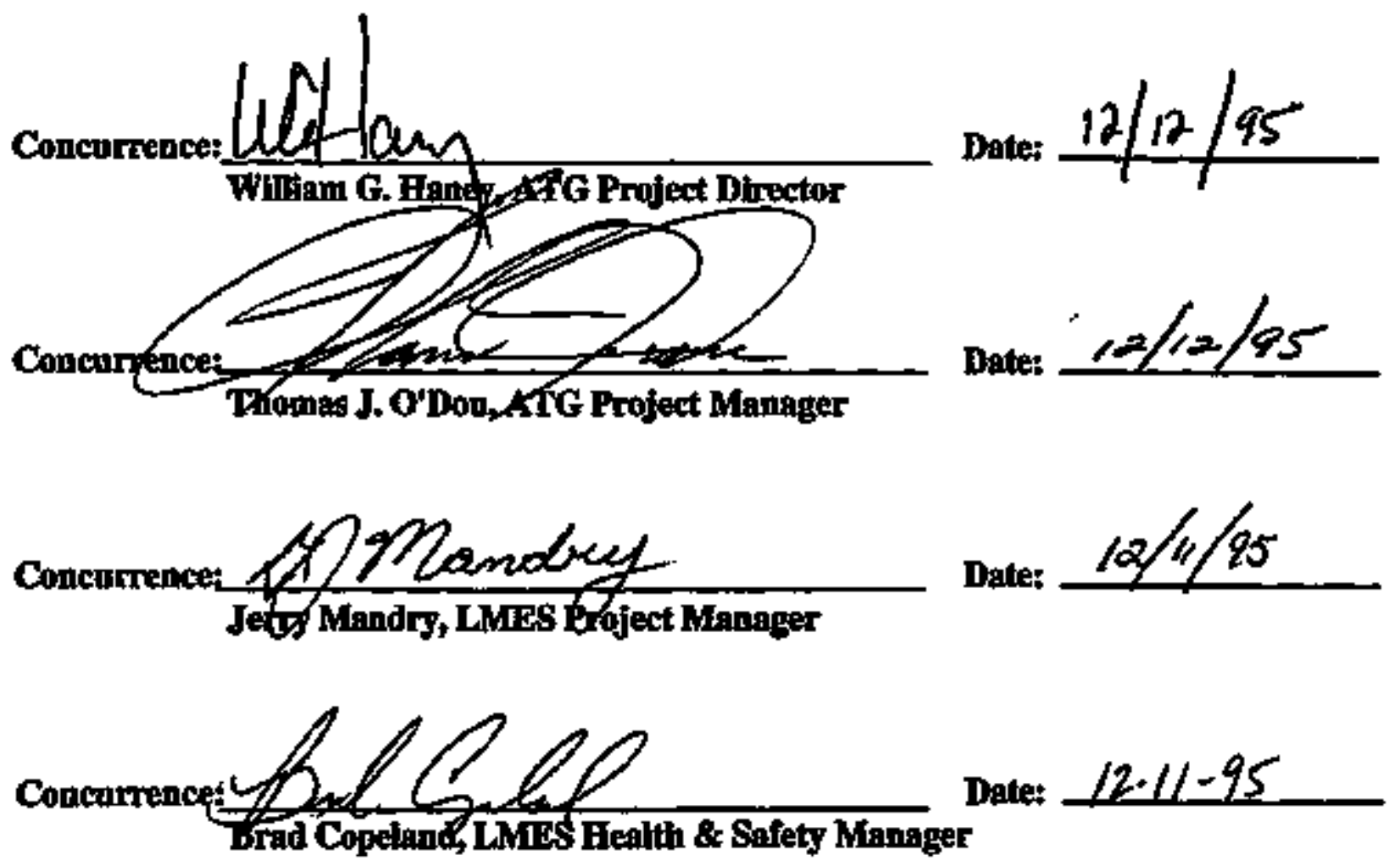



\section{CONTENTS}

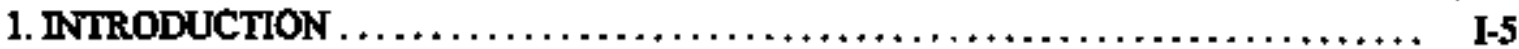

1.1 HISTORY OF BUILDNG $3506 \ldots \ldots \ldots \ldots \ldots \ldots \ldots \ldots \ldots \ldots \ldots$, I.5

1.2 DESCRIPTION OF BUILDING $3506 \ldots \ldots \ldots \ldots \ldots \ldots \ldots \ldots \ldots \ldots$, I.5

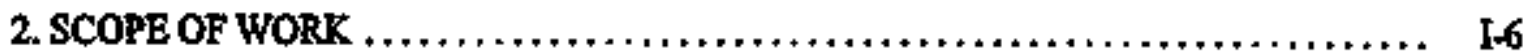

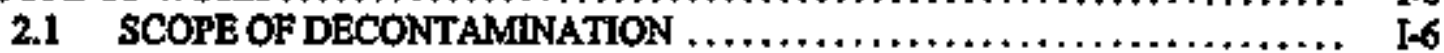

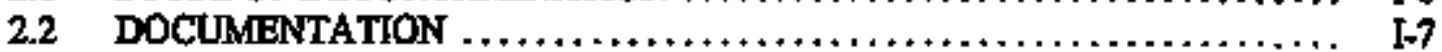

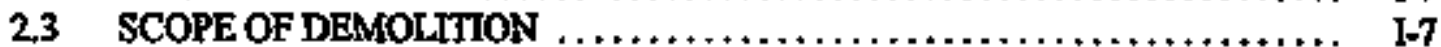

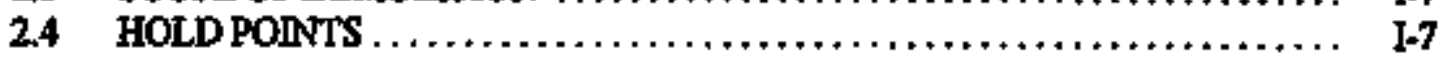

3. SITE PREPARATION $\ldots \ldots \ldots, \ldots \ldots, \ldots, \ldots, \ldots, \ldots, \ldots, \ldots \ldots \ldots, \quad$ I-9

4. FACLITY DECONTAMINATION $\ldots \ldots \ldots \ldots \ldots \ldots \ldots \ldots \ldots \ldots \ldots \ldots, 1.10$

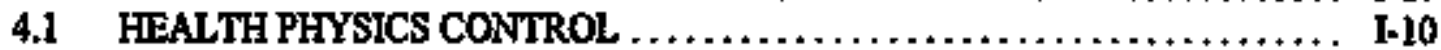

4.2 ASBESTOS-CONTAINING MATERIALS (ACM) $\ldots \ldots \ldots \ldots \ldots \ldots \ldots \ldots$ I 10

4.3 LEAD REMOVAL $\ldots \ldots \ldots \ldots \ldots \ldots \ldots \ldots \ldots \ldots \ldots \ldots \ldots \ldots, 1,11$

4.4 ELECTRICAL CONDUIT, FIXTURES, AND OTHER LOOSE MATERIALS . I-11

4.5 GALLERY CONTAMINATED PIPING/EQUIPMENTMMETAL REMOVAL .. I-11

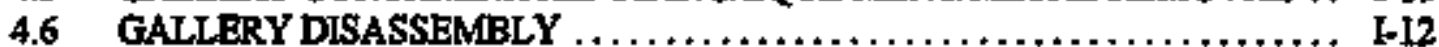

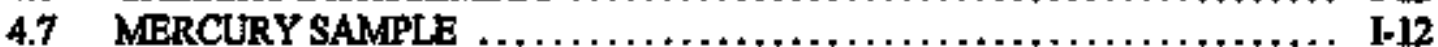

4.8 MERCURY CONTAMINATED SOI $\ldots \ldots \ldots \ldots \ldots \ldots \ldots \ldots \ldots \ldots, \mathrm{f}, 13$

4.9 DECK PANEL CELL COVERS $\ldots \ldots \ldots \ldots \ldots \ldots \ldots \ldots \ldots \ldots \ldots \ldots, \quad$ b13

4.10 CELL WATER REMOVAL $\ldots \ldots \ldots \ldots \ldots \ldots \ldots \ldots \ldots \ldots \ldots \ldots, \quad 1.13$

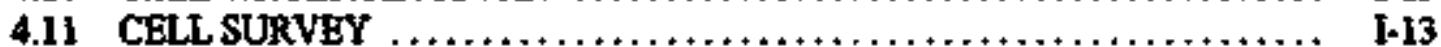

4.12 CELL DECONTAMINATION ................................, $1-14$

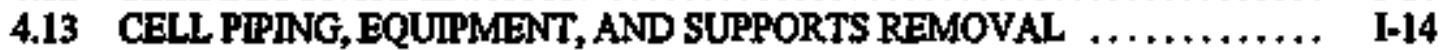

4.14 CELL DRADNAGE $\ldots \ldots \ldots \ldots \ldots \ldots \ldots \ldots \ldots \ldots \ldots \ldots \ldots \ldots, \quad \mathrm{I}-14$

5. CELL DEMOLITION $\ldots \ldots \ldots \ldots \ldots \ldots \ldots \ldots \ldots \ldots \ldots \ldots \ldots \ldots \ldots \ldots \ldots \ldots \ldots, \quad$ I-15

5.1 GALLERY DEMOLITION $\ldots \ldots \ldots \ldots \ldots \ldots \ldots \ldots \ldots \ldots \ldots \ldots$, l-15

5.2 CELL DEMOLITTON ....................................... I-15

5.3 GEOTEXTILE FABRIC, SAND FILL AND COMPACTION, GEOMEMRRANE LAYER $\ldots \ldots \ldots \ldots \ldots \ldots \ldots \ldots \ldots \ldots \ldots \ldots$, I-16

5.4 SOL FLL AND COMPACTION $\ldots \ldots \ldots \ldots \ldots, \ldots, \ldots, \ldots, \ldots, \quad$ I-16

6. ENVIRONMENTAL PROTECTION $\ldots \ldots \ldots \ldots \ldots \ldots \ldots \ldots \ldots \ldots \ldots \ldots, \quad 1-18$

6.1 EROSTON CONTROL $\ldots \ldots \ldots \ldots \ldots \ldots \ldots \ldots \ldots \ldots \ldots \ldots, \quad 1-18$

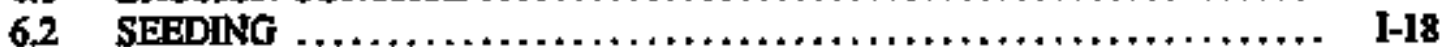

Appendix A. HEALTH, SAFETY, AND ENVIRONMENTAL, PROTECTTON PROCEDURE FOR EXCAVATION OPERATIONS (M-116): RADIOLOGICAL SOL HANDLING CRITERIA ................ A-1

Appendix B. WASTE EVAPORATOR FACIITY DEMOLITION PROJECT SIIE-SPECIFIC BEST MANAGEMENT PRACTICES PLAN $\ldots \ldots \ldots \ldots$ B-1

Appendix C. ENVIRONMENTAL MANAGEMENT PLAN FOR THE WEF DEMOLITION TASK ORDER PROJECT $\ldots \ldots \ldots \ldots \ldots \ldots \ldots$, C- 



\section{INTRODUCTION}

This Allied Techmology Groun, Inc. (ATG) Project Work Plan details the limited decentamination and disassembly of the Waste Evaporator Facilty (WEF) Building 3506 at the Oak Ridge Nationai Laboratory (ORNL). This facility currently is not used and is contaminated with hazardous and radioactive anaterials as described in Service Contract Specifications for Decontamination and Demolttion of Bullding 3506, Project Order No. 9440020.01, "Decontamination and Demolition of Building 3506 at Oak Ridge National Laboratory" (Enesgy Systems 1995a). Lirrited decontamination and distassembly will be accomplished by performing all tosks safely, efficiently, and cost-effectivety with appropriate protection of the environment and the benith and safety of workers and the general publit. The work instructions and requirements of the ATG work plan for this project shall be reviewed with the work force prior to the stnrt of work and shall be adlered to at all times while on the work site. Personmel entry into any work area is not permitted without prior approval of the ATG site supervisory staff.

\subsection{FISTORY OF BULDING 3506}

From 1949 unfil 1954, Bwilding 3506 receved liquid, low-level waste (LبLW) from ORNL operations for concentration of radiochemical waste before disposal. Based an surveys performed during 1993 and 1994, the gnllery hus a few identified "hot spots" of radiological contamination. The cell area is contaminated The highest levels of contamination are in the cell lloor sediments and fixed within the cell's cancrete floor. The primary radiologital cantaminant is the gannma-emitting isotope ${ }^{13} \mathrm{Cesium}$ The general area exposure rate in the gatlery is $<1 \mathrm{mR} /$ hour and ranges from 1 to $5 \mathrm{mR} / \mathrm{hour}$ in the cell. Sampling of the cell floor sediment indicted the presence of polychloringted biphenyls (PCBs) gaenter than the Toxic Substances Control Act limit of 50ppm. Cadnium, chromium, lead, and mercury (Hg) wero also detected in the cell flopr sediment at levels that would be expected to fail the Resource Conservation and Recoway Act of 1976 (RCRA) Toxicity Charucteristic Leuching Procedure (TCLP). Mercury was also detected in the crawlspace soil wnder the enst gallery at a level expected to fail the TCLP analysis. There are also eight kead shielding plates altaxhed to the interior walls that will be classified as low-level radionctive mixed waste.

\subsection{DESCRTPTION OF BUILDING 3506}

Building 3506 has a reinforced-conerete cell covered with three, steel deck plates, a concrete floor lined with stainless steel, and an operating gallery along the enst side of the cell. The rectangular cell is 10.2 by $4 \mathrm{~m}$ ( 28 by $13.5 \mathrm{ft}$ ) and extends approximately $2.2 \mathrm{~m}$ (6ft) below grade and $4.9 \mathrm{~m}$ (13,5ft) above gradc. The conkrete walls are $0.7 \mathrm{~m}$ (2ft) thick in the northern bolf and $1 \mathrm{~m}$ (3ft) thick in the southern half of the cell. The operating gallery extends $11.6 \mathrm{~m}$ (32ft) north to south and $3.3 \mathrm{~m}$ (9ft) east to west The walls were coststructed primarily of concrete block. The floor is approximately $2.7 \mathrm{~m}$ (7.5f) high, and lockated under the gallery. The bevilding originally had a second floor atecess to the north side of the building and a small box on the west side of the building where two pipes extend from the building into an unidentified piece of equipment (Eechtel 1994a). 


\section{SCOPE OF WORK}

ATG shall provide all necessary personnel to decontarninate and demolish the Waste Evaporator Facility, Building 3506, at the Oak Ridge National Laboratory in a safe and efficient manner, in accordance with the Lockheed Martin Enercy Systems (Energy Systems) "Request for Proposal No. KEP03-18" dated August B, 1995. All work on this subject shall be contirolled in accordanoe with regulatory and site specific requirements. This scope is based on preliminary assessment and potential hazards as identified in the Site Characterization Report, ORNL/ER/Sub/87-99053/72 (Bechtel 1994), and may be re-evaluated or modiffed to improve efficiency or worker safety wilh the concurrence of the ATG Corporate Health Physicist or the Director of Remediation.

\subsection{SCOPE OF DECONTAMINATION}

Remove, package, and perform decontamination on the following comtaminated components, streenires, and hazandous materials. The work to le performed slall be described in this work plan

1. Rernove and package all ashestos-containing material (ACM).

2. Remove and package all loose paint flakes as lead-containing waste.

3. Renove and package electrical concuit, electrical fixtures and other tocse materials.

4. Remove and package the sted piping. equjpment, supports, cast iron piping and other miscellaneous metals.

5. Remove, decontamingte and release the steol deck panel cell covers and stainless steel roof pan.

6. Remove, package and deliver lead patches to the Facility Manager, and decontaminate concrete areas (as required) located under patches.

7. Remove and package wall sections containing pipe sleves located in the gallery/cell common wall.

8. Remove and package remaining roof materials, except for those in Item 5 above.

9. Remove and package doors, stud walls and miscellaneous wood items.

10. Rernove and poukage merary- and sadionuclide-contaminated soil from the fior of the crawispace.

11. Remove water from the cell; and remove comtaminated sediment.

12. Core drill tuo drainage boles with a 1-in minimum diameter (4-in. recommended); one through the cell sump and one through the below-grade wall of the crawlspace.

13. Decontamimate stained strip, approximately 15 sq ft, on south cell wall.

The various waste streams will be segegated according to their hazard class such as Toxic Substance Control Act waste, RCRA waste, mixed waste, low-lewel waste, etc. 
The materials from Building 3506 will be handled in accordance with requirements of the performance specification and Division 1, Section 01550, "Waste Disposal" of the Service Contract Spectfications for Decontamination and Demotition of Bullding 3506 (Energy Systems 1995a).

\subsection{DOCUMENTATION}

Data collection strall be fully documented on the appropriate data record and daily project logs. All records sheill be as complefe and thorough as possible, legible, and in ink. Pessonnel making a change to a record shall cross out the old entry with one line, add the new information, and initial and date the change. Under no cireumstances shall the old entry be seratched out, whited out, erased, or otherwise removed or made illegible.

When applicable, an explanation shoald accompany the change or correction. The ATG Site Superintendent shall maintain all logs.

\subsection{SCOPE OF DEMOLITION}

Renowe and package the components and struchures as indicated below, The work to be performed shall be described in this work plan.

1. Remove gallery floor and building walls to lft below grade, and also remove exterior sidewalks and concrite pads. Use denolition concrete as clean fill in the below-grade volume of the building. Do not damage the Valve Pit.

2. Use demolition concrete which meets the definition of Category 2 material per the ORNL procedure, Health Safety, and Envinnmental Protection Procedure for Excavation Operotions, M-116, "Radiclogicai Soil Handing Critaria" (see Appendix A of Part I) to fill crawkpace and cell volume to lft below grade. Minimize voids.

3. Excess building materials shall be transported to the Y-12 Sanitary Landfill for disposat. Only releasable materials will be sent to the Y-12 Sanitary Landifll.

4. Cover with geomembrane, backfill, compact, and seed tbe backfill.

The materials from Building 3506 will be handled in abcordance with requirements of the performance specification, Division 1, Section 01550, "Waste Disposal" tin the Service Contract Specifications (Energy Systems 1995a).

\subsection{HOLD POINTS}

The sequencing of the following work activities is at ATG's discretion. However, the following HOLD POINTS shall be athered to:

1. Do not proceed with demolition without written approval from the Facility Manager.

2. All floor drains and perimeter wall openings which ofter tosonable potential for allowing hazardous moterials to enter the environment shall be pluged prion to hapardens material abntement Notify the Facility Manager immediately upon completion of drain/opening plugging 
for confirmation of acceptable plugging. Do not proceed with hazardous material abatement without written approval from the Facility Manager.

3. Hazardous and radiogctive materitl removal shali be completed in accondance with Section 4 of the ATG Health and Safery Plam prior to building demolition. Removal of roofing and exterior equipurent/materials may proced concurrently with building interior decontamination. Notify the Facility Manmer immediately upon completion of removal for confimation of acceptable hazardous and radionctive material removal. The Energy Systems representative will verify that material is properly segregated and packaged prior to approval for disposition. 


\section{SITE PREPARATION}

The following tasks shall be performed prior to actual remediation:

1. Before work begins, all tooks and related equiponent shall be screened for radionative contamination by the Fagility Manager's Health Physius (HP) personnel. After completion of work, tools and related equipment will be screened again and decontaminated as necessary.

2. A barrier shall be erected around all work areas and shall be properly posted for both radiological and industrial safety hazands.

3. Sot up on-site facilities: control point, emergency decomtamination facility, and entrance and exit points to controllet area.

4. Verify, physically andor by test, that all utilities, inchuding electrical services on the building are discomnected, Contant the Fayility Manage and verify that live control fines serviting other facilites have been relocated from the east comer of Buikling 3506. Varify that all water lines are deptessurizod or disconnected prior to demolition. Plysical verification stiall be performed pariodically during demolition activities as well as prior to the initiation of each work shiff. The Facility Munager will be responsible for lockouttagout on all systems requirutg lockouttagout. ATG will be responsible for pplying its ovortags and locks in accordance with Division 1 spocifications (Evergy Systems 1995a).

5. Build protective structures around the valve pit and small but vital foxtures outside the building. If possible, the valve operators will be removed at the base, and will be reattached at the end of the project,

6. Energy Systems will specify the location(s) and ATG will prepare laydown areas for clean and contaminated matraials.

7. Energy Systems will specify and ATG will remove unnecessary external structures to minimize obstructions and interference.

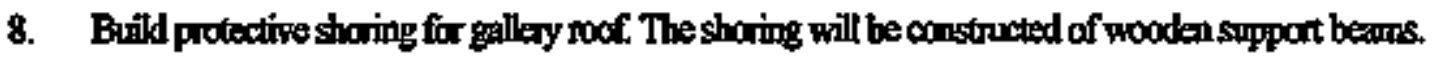

9. Pug all drains and holes, then get written permission from the Facility Marager to proceed.

10. A containment tent will be erected over the building prior to the start of work. The tent will be instulled by ATG in accordance with the manufacturer's installation instructions.

11. The Facility Manager shall provide $B-25$ boxes and drums. These shall be placed in the appointed equipment storage areas.

12. Inform the Facility Managre immediately of any significant unusual or deteriorating conditions of the building discovered during work activities.

13. Appropriate personal protective equipment (PPE) and insulated tools will be used by ATG each time any electrical circuti (including those verified as de-energized) is to be cut.

14. Spill coutrol kt's that consist of a shovel and a 55 -gal dnum containing absorbent pigs, gloves, shoo scuffs, and a Tyvek suit will be ar-site during this project. 


\section{FACILITY DECONTAMINATION}

Workess shall deccontmimite the galley and ofher equipment as nectessary in a manner to minimize

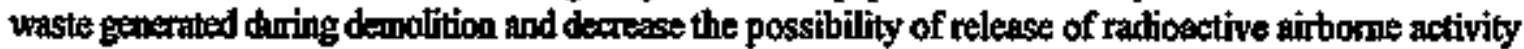
inside the tent. The decontamination method for radiclogical contamination shall consist of soap and water solution and disposable towels. Any abrasive methods shall be perfomed with ATG Supervisor approval only. Locations where radiological decontanimation is needed will be identified by the HP technicians by outlining contarrinated areas with spray paint during the pre-job survey. The $\mathbf{H P}$ technicians shall then re-survey the areas after decoptanination to ensure all contamination bas been removed. If decontamination is unsucesssfinl after a third attent, then the ATG Supervisor shall perform an evaluation before ary further decontamination is allowed.

\subsection{HEALTH PHYSIOS CONTROL}

After initial HP surveys, all work that involves exposing previously unsurveyed surfaces, shall be peformed by HP. A daily routine survey schedule shall be established by HP. Radiological surveys shall be performed by HP technicians using handheld ion chamber dose rate meters and Geiger-Mollor firiskers or equivalent. All instenments shull be in proper working order, response checked daily, and be within the calibration due date. Copies of calibration certificates shall be kept on-site. Surveys will be performed to identify the following radiological conditions:

- fixed surface contsmination

- loose surface contamination

- general area dose rates

- "hot spot" identification (radiclogical "bot spots" are defined as a radiation source that is five (5) times general area dose rate and/or grealier than or equal to $100 \mathrm{mR} / \mathrm{hr}$ a: $30 \mathrm{~cm}$ )

- air quality

\subsection{ASIBESTOS-CONTAINING MATERIALS}

ACM was found in the window putty and in the roofing felt in the gallery. This task will require workers who have successfilly completed Asbestos Worker training and are tratiued in asbestos handling technignes and healfitoafty thiques associated with that finction.

1. Remove gallery windows; asbestos in patty. The window pulty will not need to be removed, wiondows can remain intact, and will be disposed of in plestic wapping intact.

2. Remove gallery roof top (stainless steel). Survey roof top for possible clean release. Expose tar paper folt. Ths asbestos is in the roof fell

3. Remove the roof fet by hand. Any felt that has achered to roof top will be loosened with water and temoved with flat head shovels.

4. PPE requirements for all work involving ACM will be described in Section 4.1.I. of the ATG Healh and Safety Plon. 


\subsection{LEAD REMOVAL}

Loose paint chips may exist on any painted surfaces. Removal will require workers who have successfully compited ATG Leud Worker training and are trained in lead handling tectiniques and health/safety techniques associated with that fonction.

1. Remove and package loose paint chips in the interior and on the exterior of the betilding. Scrape or chip old paint as necessary to prevent exposure to workens, Only locse flaking paint needs to be removed Removal of loose paint chips will be performed with putty knives and catch basins.

2. Decontaminate, remove, package, and deliver to the Facility Manager the lead patches covering pipe sleeves in the west gallery wall and the six lead patches located on the east wall of the cell. This tak will be performod undar HP surveillance in the event that the components under the lead sleeves or patches may shield radiation "hot spots."

3. PPE roquirements for all work inwolving lead with be descrihed in Section 4.1.2. of the ATG Healh and Safety Plon.

\subsection{ELECTRICAL CONDUT, FIXTURES, AND OTHER LOOSE MATERIALS}

Electrical equipment in the building is assumed to be radiologically contaminated and not cocromical to clean and strvcy. Wiring mey conthin lead, PCBs and/or asbestos. The outside electricel equipment will be removed at the same time as the internal equipment. The inside and outside material shall be kept separate. The wire shall be staged as directed by the Facility Manager. The conduit from inside the building is to be disposed of as radioactive material inside B-25 boxes. The conduit from outside the building, misy be used to fill woids in the boxed conduit from inside-not vice verse. Do not place electrical materials in the below-grade volume. All waste will be segregated prior to packaging.

1. Verify that all electrical power is disconocted before demolition of the conduit and cable.

2. Steel conduit and pipe protrsions will be cut with a portable band saw after cut location bas been surveyed for radiological contamination by a HP technician.

3. The electrical wiring will be placed on pallets which will be stripped at a later date by Energy Systems.

4. Disconnect, renowe, and package light fixhurs. Remove and package brackets, stems, hangers, and other axcessories. Lamps are to be removed from lighting fixtures, containerized and staged for pickup by the Facility Manager. Ballasts are also to be removed, handled as polychlorinated biphenyl (PCB) waste, containerized and staged for pickop by the Facility Manager. Remaining fischuses shall be handled in accordance with Division 1, Section 01550, "Waste Disposal" in the Sentce Contract Specifications (Energy Systems 1995a).

\subsection{GALLERY CONTAMINATED PIPING/EQUIPMENTMETAL, REMOVAL}

1. Renove and package in B-25 boxes all equipment and associated piping, duct, tubing stands and supports inside the gallery and crewispace. 
2. All piping above the Ift below grade elevation, with the exception of piping slewes in the gallery west wall, shatl be cut flush with the wall or floor and the cut pieces paxkaged in B-25 boxes.

3. Al piping below the in below grade elevation should be cut flush with floor or wall. All perimeter wall piping shatl be sealed at the end by plugging.

4. Pipe skeves runing from the gallery to the cell in the common wall shall be removed intact when that portion of the coinmon wall is removed.

5. In the gallery, remove and package in B-25 boxes all steel sheet metal covering support joists, manhole cover and any other miscellaneous metal.

6. Remove, decontaminate to levels as listed in Table IV-1, "Surface Contamination Limits" in US.Department of Energy (DOE) Order 5400.5, and stage the steel deck plate covers as directed by the Facility Manager.

\subsection{GALLERY DISASSEMBLY}

NOTE: There is severe deterionation of joof materiak.

Use fall protection when above six ft.

\section{DO NOT STAND ONTHE GALLERY ROOF}

Upon completion of gallery decontamination, the disassembly phase can begin.

1. Remowe the gallery noof, vevere deterioration; survey for release as clean material; box separately from hazardous material.

2. Renove gallery doors and wooden walls on east side; survey for release as cleam; box with wood from roof.

3. Remove east walls (concrete block) (concrete may be clean) to expose gallery area inside walls.

4. Remove gallery south doos and walls; concrete miny be clean.

5. Gallery floor will be cut by the subcoutractor (Trentec) into moveable sections to reveal open crawlspace. This task will be performed by the subcontractor (Trentec) under ATG supervision. the ATG Health and Safety Plan, and the subcontractor's concrete cotting procedures.

6. Remove contets wall of gallery to grade level

\subsection{MISRCURY SAMPLE}

The soil in the crawlspace will be sampled by an ATG Industrial Hygienist (IH) for Hg concentration. In addition, samples of air in the crawlspace will be taken to determine air quality, oxygen content, and presence of explosive or toxic gases. The HP technicians will survey soil and air for radiological contaminants. 


\subsection{MERCURY CONTAMINATED SOIL}

The Hg contaminated soil will be renoved using an Excarator/Backbos or will be hand excavated and placed in B-25 bones for disposal.

1. Cove gound between B-25 bxx and cravisyace with puncture resistant poly sitating to contim bose dirt.

2. Remove all soil for entire length and width of crawlspace to a depth of $1.9 \mathrm{ft}$, or until refissal, or as directed by ths Facility Manager.

3. PPE requirements for all work involving $\mathrm{H}_{8}$ will be described in Section 4,1.3 of the ATG Heallh and Safety Plan.

\subsection{DECK PANEL CELL COVERS}

The roof of the cell is constructed of dianond plate steel.

1. Remove coves from cell structures, Survey covers for radioactive material. Control the roof deck plate as radioactive until verification by radiological surveys.

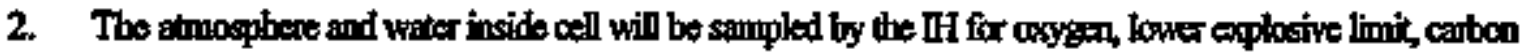

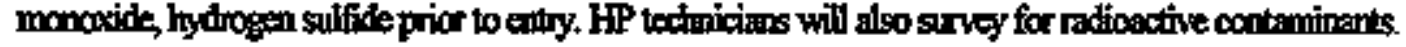

3. Peform decortaminstion of dect panets as described in Section 4 of the ATG Health ond Sofety PIan.

\subsection{CELI WATER REMOVAL}

The cell contains approximately 1500 gallons of water. The sludge and sediment in the bottom is krown to contain radiologica, RCRA, and PCB contaminates.

1. Afta stappling and analysis are complete, the water will be treated "as found" by Energy Systens Waste Operations.

2. The remaining sludge will be removed with flat head shovels into plastic disposable containers used to transport the waste from the cell to the 55-gal dnums designated for PCB storage.

\section{4,11 CELL SURVEY}

Upon completion of water and sludge removal, the cell shall be surveyed by the IH and HP tochicians for heavy metals, PCBs, and madioactive contamination. The HP survey shall be performod in order to identify the following radiological conditions inside the cell:

- foxed surfice contamination

- loose surface contamination

- general area dose rates 
- "Thot spot" identification (radiological "hot spots" are defined as a radiation source that is five (5) times the gentral area dose rate andior greater than or equal to $100 \mathrm{~m} / \mathrm{h} / \mathrm{hr}$ at $30 \mathrm{~cm}$

- air quality

\subsection{CELI DECONTAMINATION}

Upen completion of the HP survey as described in Section 4.11, cell decontamination can begin. This will consist of removal of radionative material from the cell walls and floor, as well as the lead stielding patches. A review of the cell survey by HP supervision msy warrant that the decontannination and packaging of the lead patches be performed outside the cell due to dose considerations. Remove and dispose of lead as per Section 4.3.2. PPE will be described in the Radiation Work Permit (RWP).

1. Provide high-eficionzy partizulate air (HEPA) filtered ventilation to cell,

2. Build access stains to the cell below.

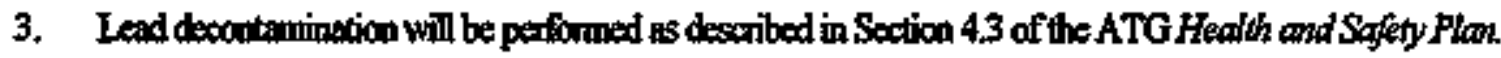

4. Concrete radiological contamination will be removed by ATG decomamination tectinicians using concrete scabbles or cther hand tools. Contarnination levels on concrete nust meet criteria of Category 2 in the Heallh, Safesy, and Environmental Protextion Procedure for Excontofion Operations, M-116, "Radiological Soil Hendling Critcria" (see Appondix A) to be placed is the below-grade area.

\subsection{CEIL PIPING, EQUIPMONT, AND SUPPORTS REMOVAL}

Piping and materials will not require decontamination because it is not considered economical

Components will be cut with a portable band saw to telp mininize the spread of contamination potentially located inside. No components shall be cut without HP approval. Each location shall be surveyed for ratiological contarmination. Engineering controls will be used during all cutting grinding, and welding on contaminated materials to prevent contamination from entering the workers breathing zone and the enviromeat. Enginesing controls shall consist of, but not be limited to HEPA veatilation, cursory decontamination, etc. PPE stall be designated in the RWP.

\subsection{CELL DRAINAGE}

Cell drainage will be attained by drilling two holes, 4-8 in. diameter, one in the crawlspace (if a foundation exists), and one in the hot cell floor.

1. Drainage holes will be filled with Number 4 course aggregate. Placs a Trevera fabric (1120 or equivalenf) cover over the holes. Twelve (12) in of Number 4 course aggegate will be placed over the Trevera fabric to allow drainage to the holes.

2. Conerete cores shall be disposed of on-site in the below-grade vohume in accordance with Category 2 criteria locsted in the, Heallh, Safety, and Entrommental Protection Procedure for Excouvation Operations, M-116, "Radialogical Soil Handling Criteria" (sec Appendix A). 


\section{BUILDING DEMOLITION}

Remove and dispose of the enst pallery, crawispace walls, and cell area down to ift below grado (except for the north cell wall). Materials shill be segregated into Category 1 and Category 2 materials in accordance with the Interim Revision located in the Health, Sofety, and Environmental Protection Procediture for Excanation Operations, M-116, "Radiological Soil Handling Criteria" (see Appendix A). Category 2 concrete shall be placed on-site in the cell and crawlspace in the helow-prade volums on a space-arailable basis. Category 1 concrete may only be used to minimize void spaces if Category 2 material is not available. The available volume shall be filled with concrete to a mininum of $80 \%$ cupacity. ATG will ensure that rebar does not protoude axore than 2 in from cut sections of the concrete in accondarce with state land disposal restrictions. Excess Category 1 materials shall be transported to the samitary landflll. Excess Category 2 materials, if any, shall be placed in B-25 boxes and staged for pickup by the Facility Manager. All effiort will be made to minimize excess materials.

\section{I GALLERY DEMOLITION}

Remove and dispose of the following components located in the east gallery:

1. Concrete masonry block south and east walls.

2. Remaining concrete west wall.

3. Concrete stair from ground level to the north doar.

4. Concrete steps up to the south door.

5. Concrete floor.

6. Brick tile flooring (set in concrete) northwest comer.

\subsection{CELL DEMOLTIION}

The cell walls will be cot into moveable blocks to facilitate removal. This task will be perfonmed by the subcontractor (Trentec) under ATG supervision, ths ATG Health and Safety Plon, and the subcontractor's conctete culting procedures.

1. Remove south and west concete walls to Ift below grade.

2. Remove north concrete wall flush with the top of the valve pits.

3. Pipe pentetrations prothuding from the cut wall sections shall be cut flush with conerete, so that storage space in the cell will be conserved.

4. All work on contaminaled material inside cell will be performed in acoordance with Section 4.13. of the ATG Heallh and Sofery Plon.

5. Remove crawlspace walls to lft below grade. 
6. Remove, package, label, and stage for pickup by Energy Systems Waste Operations the following components exterior to Building 3506:

- conugated metal awrings,

- metal stairs and handrails,

- metal platforms and framing.

- concrete walk on west side of the building up to the Valve Pit,

- concrets walk and pad on south side, and

- any miscollaneous material associated with Building 3506.

\section{GEOTEXTILE FABRIC, SAND FILL AND COMPACTION, GEOMEMERANE LAYER}

1. Priur to the installetion of the geotextile fabric, proofroll the demolition debris with a dozer and/or other heavy tracked equipment to stabilize fill, enhance consolidation, densify the surface, and to produce a smooth and reasonably wniform slope. Remove sharp objects such as jagged-edge rubblo or concrete reinforcing bars, which could punchure the geotextile fabric. Demolition debris shall be propfrolled until the finisted surface is acceptabls to the Faxility Manager.

2. Install geotextile fabric over compacted demnlition debris in accordance with mamuracturer's recommendations and as shown on Sketch SK-C02 (Energy Systems 1995a).

3. Spread a sand layer over the geotextile fabric in a mamer which does not damage the geotextile fabric. Compact the sand with a minimum of four (4) one-way passes with a smooth steel-dnum roller. Shape the sand layer to pronote positive drainage away from the building. Adifust the noisture content of the stand as required for workability.

4. Afte placenent of the sand layer, and prior to installation of the geomembrane liner, proofroll sand layer to remove nuts, ridges, sharp objects, and other imperfections. Areas that pump, rut, or deform excessively during rolling shall have additional sand material added and compacted until stabilized.

5. Install geonembrane liner as shown on Sketch SK-C02 and in accordance with manufachurer's installation procecheres (Energy Systems 1995a).

\subsection{SOIL FILL AND COMPACTION}

1. Spread fill material to be compacted in lifts that will not exceed fin after compaction.

2. After placement of locse material, adjust moishure content as recessary for workability and compaction.

3. Compact all tifts of soil fill using a minimum of fow (4) onowry passes with a smooth, steel finm

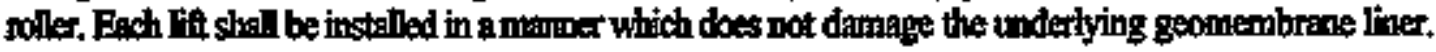

4. Grade to drain away from struchures and to prevent ponding. Finish surfaces free from irrogular surface changes. Finished sufaces sholl have a minimum slope of $0.5 \%$. 
5. Do not place fill material when weather conditions, condition of the subgrade, or condition of the fill materinl precludes obtaining adequate compaction. Do not use frozen material for fill, and do not place fill material on or agdinst frozen surfaces.

6. After final grading has been achieved the soil layer shnll be proof rolled with a smooth, steel dinm roller. Areas that pump, rut, or protnude excessively during proof rolling shall be scarified, conditioned, and recompacted to stabilize arens. Areas that can not be conditioned to achieve an acceptable surface as detronined by the Facility Managar shall be undercut and replaced as directed by the Facility Manager. 


\section{ENVIRONMENTAL PROTECTION}

The following eavironmental concerns shall be addressed as follows:

1. Any required digging will be performed in accordance with the excavation and penetration permit (which con be obtained from the Facility Manager).

2. Provide dust control and dust monitoring throughout work netivities to prevent visible dust emissions from reaching Third Stret and Central Avenue on the ORNL property.

3. Contrul and monitor/sample for aiborne radioactivity to ensure that concentrations of redionative material in the air outside the project fence do not exceed values in Figure 1 (Energy Systems 1995:).

4. Provide packaging for loose waste and salvageable metterials during transport. Ensure that no waste is allowed to fall off the trucks during transportation. In the event that waste is lost during trasportalion, ATG will be respornsible for the cleamup. This includes both public highways and plant roads.

\subsection{EROSION CONTROL}

Control of surface water runoff and soil stabilization will be accomplished by installing slope protection and erosion confrol using straw bale barriers entrenched in a row (Energy Systems 1995a).

\subsection{SEADING}

Provide sted mixture in containers showing percentage of seed mix, year of production, net weight, dats of packagitg, seeding dates, and location of packaging. See Appendix C. "Foster Wheeler Envirommental Corporation DOE-ORO ERWM Program-Seeding", in the Service Contract Specificotions (Energy Systems 1995a).

If it is decided that the containment tent shall remain over the site upon completion of denclition activities, seading of the area will not be necessary. Refer to the Facility Manager for direction. 
Appendix A

HEALTH, SAFETY, AND ENVIRONMENTAL PROTECTION PROCEDURE FOR EXCAVATION OPERATIONS (M-116):

RADIOLOGICAL SOIL HANDLING CRITERIA 



\section{INTRODUCTION}

These soil handling criteria were developed to provide a safe and practical methodalogy for dealing will contaminaled soil in the field. Radiological characteristics for Category 1 soil are based on current "green tag" límits. Radiologinal characteristios for Category 2 soil are based on an exposure rate redinction factor of 100 through use of at least one foot of uncontaminated backfill, Category 2 soil used as backfill in areas that will be continuonsly cocupied should not result in dose rates greater than 0.25 $\mathrm{mrad} / \mathbf{h}$.

These criteria define radiologicat limits which are measurable with field instrumentation and provide an acceptable level of radiation safety for workers and persons exposed to this soil when used as backfill. THESE CRITERIA ARE INTENDED FOR SOLS LOCATED ON AND REMAINING ONTHE OAK RIDGE RESERVATION WHERE INSIITUTIONAL CONTROL IS IN PLACE. 


\section{RADIOLOGICAL SOIL HANDLING CRITERIA}

\section{CATEGORY 1}

This soil has norestricted use on the Oak Ridge Reservation. Dircet measurements taken at the surfice of the soil are less than $300 \mathrm{pm} / 100 \mathrm{~cm}^{2}$ alpha and less than $0.02 \mathrm{mrad} / \mathrm{h}$ beta/gamma. Smear counts firom equipment that contacted the soil are los then $20 \mathrm{fpm} / 100 \mathrm{~cm}^{2}$ alpha and less than 200 $\mathrm{dpm} / 100 \mathrm{~cm}^{2}$ beta/grame If there is historical evidence of alpho or low-energy beta contamination, the soil should be analyzed in the laboratory.

Depenifing upon the history of the area being excavated, the lovel of allowable activity will vary. If the excavation is in an area in which no radio processing or radioactive spills have occurred, it can be safely assimed that any alphe activity is dwe to nabural uranium and/or thorium foumd in soils of ORNL. In this case the allowable limit for alphs activity is $0.8 \mathrm{~B} q / \mathrm{g}$ gross alpha. However, if the excavation is in areas of know radio processing or radioactive spills, all alpha comtamination will be assumed to be transuranic contamination and the allowable limit will be 0.33Bq/g gross alpha, The beta/gamma activity in any case must be less than $5 \mathrm{~B} q / \mathrm{g}$. Any soil with activity greater than these kevels may not be used in an unrestricted manner, but must be considered "contaningted" soil. If there is, the allowable limit for alpha activity is 0.8B $/ \mathrm{g}$ gross alpha. However, if the excavalion is in areas of know radio processing or radioactive spills, all alpha contamination will be assumed to be transuranic contamination and the allowable limit will be $0.33 \mathrm{~B} / \mathrm{g}$ gross alpha. The beta/gamma activity in any case must be less than 5Bq/g. Any soil with activity greater than these levels may not be used in an unrestricted manner, but must be considered "contaminated" soil If there is a result, if the measured value is greater than 1.645 times the measurement uncertainty divided by two, the result is statistically significant. If either of these limits are exceded, the soil should be considered "Categary 2." Soil with a uranium/thorium level in oxcess of $1 \mathrm{Bg} / \mathrm{g}$ can be approved as "Category 1 " soit if it can be demonstrated that the uranium/thorium content is typical of that type of soil.

\section{CATEGORY 2}

Soil in this category may be used for limited backfilling. Measurements at the surface of this soit are grcater than $300 \mathrm{dpm} / 100 \mathrm{~cm}^{2}$ and less than $6000 \mathrm{dpm} / 00 \mathrm{~cm}^{2}$ alpha and equal to or greater than $0.02 \mathrm{mrad} / \mathrm{h}$ but less than $5.0 \mathrm{mrad} / \mathrm{h}$ beta/gamme

Soil in this category may be used for backfill at the site of origin or in a Contamination area of similar radiation kevels, provided that the area to be backfilled is not intended for continuous human occupation. In each location where Category 2 soil is used as backfil, at least one foot of clean unontaminated soil must be placed over the contaninated backfil, and the site must be identified as a maintained area and murked on maps that are kept updeted. In no case should contaminated soil be used as backfill in uncontaminated areas.

Soil not needed for backfill shall be considered as Radioactive Waste (Catogory 3) and sent, aftor proper packiging to the designated Solid Waste Storage Area (SWSA).

\section{CATBgORY 3}

Soil in this categcry may not be used for backfill but will be considered as Radioactive Waste and sent to the designated SWSA. Surface readings are equal to/greater than $6000 \mathrm{dpm} / 100 \mathrm{~cm}^{2}$ atpha or exual to/getater than $5.0 \mathrm{mrad} / \mathrm{h}$ beta/gamma. 


\section{Appendix B}

WASTE EVAPORATOR FACILITY DEMOLITION PROJECT SITE-SPECIFIC BEST MANAGEMENT PRACTICES PLAN 

B-3

\section{CONTENTS}

1. PROFECT PURPOSE AND DESCRIPTION,$\ldots \ldots \ldots \ldots \ldots \ldots \ldots \ldots \ldots \ldots$, B-5

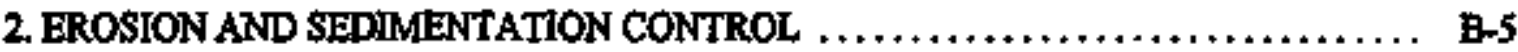

3. STORMWATER DRAINAGE $\ldots \ldots \ldots \ldots \ldots \ldots \ldots \ldots \ldots \ldots \ldots \ldots \ldots \ldots$, B.6

4. SITE RESTORATION $, \ldots \ldots \ldots, \ldots, \ldots \ldots, \ldots, \ldots, \ldots, \ldots, \ldots, \ldots, \ldots, \quad$ B-6

5. TRARNNG $\ldots \ldots \ldots \ldots \ldots \ldots \ldots \ldots \ldots \ldots \ldots \ldots \ldots \ldots \ldots \ldots \ldots \ldots, \quad$ B-7

6. SPLLL PREVENTION AND WASTE DISPOSAL $\ldots \ldots \ldots \ldots \ldots \ldots \ldots \ldots \ldots \ldots$, B-7

7. SITE INSPECTIONS AND MONITORING $\ldots \ldots \ldots \ldots \ldots \ldots \ldots \ldots \ldots \ldots$ B-8

8. WASTEWATER DISPOSHTION $\ldots \ldots \ldots \ldots \ldots \ldots \ldots \ldots \ldots \ldots \ldots \ldots \ldots \ldots \ldots \ldots \ldots$, B-8 



\section{PROJECT PURPOSE AND DESCRIPTION}

Building 3506, the Old Weste Bvaporator Facility (WEF), was canstructed in 1949 and housed the first liquid waste evaporator at ORNL. The WEF received liquid, low-lovel waste (LILW) from laboratories and isotope processing areas for concentration. After the LLLW was processed, the condensate was transferred to the Process Waste System; the concentrate was then transferred to the Gumto Tanks in the North ardicr South Tark Farms. In 1954, the WEF was replaced by Building 2531 (Radioactive Waste Bvaporator Facility) and was splisequently used as an experimental radioactive waste incincrator and a rare-earth element separations experiment facility. In the 1980s, the facility was usod as a changing room for personnel working in the North and South Tank Farm area.

Building 3506 is approximately 32ft by 23ft and consists of three main areas; worth cell, south cell, and main gallery. The north and south oells are constructed of poncrete walls that are 2 and 3ft thick, respectively, and oxtend to a depth of $6 \mathrm{ft}$ below grade. The concrete wall that once separated the north and south cells was removed to produce a single cell area. The roof over the cell ares consists of 0.25 in. thick steel deck plates which must be removed to gain acoess to the area. The building originally included a second floor that provided tocess to the cells, but the second floor struchure and interior staiss leading down into the cells have been removed. The gallery area is a wood structure except for the floor and west wall which are made of concrete. All equipment has been removed from the gallery, and cell areas and all piping catering/exiting the builimg have beon ranowed and piugged. Based on the condition and the presence of ratiological contamination within the facility, Building 3506 has been targeted for demolition to reduce or eliminete the potential for exposing personnel working in the Noth and South Tank Farm areas to residual contanintation associated with the building.

The project will involve demolition of the above-grade portions of the Waste Evaporater Facility. This wonld mome an obstacle inhibiting access in the Sonth Tank Farm and would facilitate the continued remedial activities at the Gumite and Associated Tanks Operabie Unit. The proposed action includes:

1. Renoving and packaging radioactive and mixed waste streams genterated as a tesalt of demolition activities;

2. Plecing bevilding concrete in the below-grade portion of the facility;

3. Providing limited decontamination to facilitate demolition;

4. Stmpling and analysis for waste characterization and certification; and

5. Placing a geomembrane over the site, covering it with $1.5 \mathrm{ft}$ of backfil, compacting the backfill area, and seeding/stabilizing the backffil area.

\section{EROSION AND SEDIMENTATION CONTROL}

Waters of the State of Tennesses can be inpacted vis discharges from the ORNL stomn sewer network. Gridanee from the Tennessee Erosion and Sediment Contmol Handbook (attached) will be utilized for protection of the waters of the State through effective mankgement practices during site 
preparation and demolition activities. The goal of erosion and sedimentation controls is to minimize the impact project activities have on downstream water qualify, inchuding stormwater in ORNL storm sewers. Frequeat vehicaler traffic in vegetated areas, especially in the winter months, can create erosion and sextimentation problems. The stommwater in this area drains generally from northeast to southwest toward Third Street on the west side of the site and to a paved alley on the south side of the site. If significint distumbarce of vegetated areas cocurs, silt feoces andor straw bales will be placed along these bolundaries to preclude seifinentation from the site.

Erosion and sedimentation controls will be installed, as needoct, prior to the beginning of demolition activities md will be maintained throughout the duration of the constnuction phases. Silt fences will be installed down gradient of larger, distubed areas to pond shet flow ranoff behind them and minimize sedimentation from the demolition site. Special sedimentation controls will be placed around nearby sterm sewer catch basims which receive rumoff from this site.

Straw bale barriess will be used in chanels and oriented perpendicular to the channel with ends of adjacent bales tightly abutting to one another. The straw bale barriers will be constructed so that water will flow through the barriers during low storm nunof. The barier elevations will be designed so that a high flow storm noffi will over-top the barrier instead of ninning around the ends of the barrier. The silt fences and straw bale barriers will be inspected by the Construction Engineer or designee immeciately after each rainfal and at least once daily during prolonged rainfall. Repairs will be made as necessery. The collected sediments will be renroved when deposits reach one-third the height of the barrier. Collected sediments will be managed and labeled appropriately for final disposition by the Project Generator Certification Official.

Temporary seading should be applied where final grading of exposed surfaces are to be completed within 15 days to a year. Areas where final grading is not planned for more than one year should be seeded under the permanent seeding guidelines. Such areas include demuded areas, soil stockpiles, dikes, dans, or temporary diversions. All erosion and sedimentation controls installed during the demolition will be modified as conditions change to protect the quality of runofr leaving the site.

\section{STORMWATER DRAINAGE}

Stanwater run-oa will be diverted arcind the work area to prevent its contamination and need for treatument or detemtion before final disposition.

\section{SITE RESTORATION}

The below-grade pations of Builing 3506 will contain construction debris from the above-grade portion of the fuility to the maximum extent possible. A geomembrane will be placed over the site and covered with 1.5f of backfill. Exposed soil will be graded and seeded or stabilized. Temporary erosion controls such as silt fencing and straw bales will be removed when all exposed soil is permanently and adequatcly stabilizod. 


\section{TRAINING}

ORNL malpyos neceive a broad range of enviropmental, safety, and health training based on job requirements. Additionally, envirotumental nwareness is raised by issuing periodic bulletins concening topios such as spill control. Supervisors are responsible for providing on-the-job training with respect to hazardous materials handling hod ORNL environmental policy.

\section{SPILL PREVENTION AND WASTE DISPOSAL}

All waste generated will be managed, stored and disposed of according to applicable statutes, regulations, DOE Orders, and Energy Systoms procedures.

The ORNL Spill Prevention, Control and Countermeasures (SPCC) Plan provides details concerning the roles and responsibilities of personnel responding to releases of oils or other hazardous substances. \$ummarized below are portions of the SPCC that apply to the Waste Evaporator Facility Demolition Project.

The Construction Enginer is charged with responsibility to ensure that effective spill preventative mesures ere in plase. A nest and orderly work environment will be maintained to reduce the possibility of spills or other environmentally deleterious incidents. The Office of Environmentul Compliance and Documentation (OECD) Field Oversight personnel will provide oversight and guidarce.

The ORNL SPCC Plan requires all possible precautions to be taken to minimize the likelihood of a spill or release. In the event of such, the Plan requires safe containment and/or recortery in a manner that best assures personnel safety and protection of the environment.

Tarks, drums, and otha containes of oils, fivels, or hazardous or toxic materials, such as solvents, detergents, and degreasers will be stored such that a leak or spill will not flow into a stom sewer catch basin. If more than 110 gallons of any combination of thesse materials is stored on-site, secondary containment will be provided for the tank(s) or dnum(s). Products sbould be kept in original labeled containers along with manufacturer' protuct information whentever possible,

Heavy equipmalt and mochanioal equipment will be maintained in good repair to assure that stow leaks of engine, transmission or other oil are minimized. Ifle equipment will be parked as far away from stream beds or drainage ways as practicabtt. At the request of the Construtetion Engineer, a drip pan will be placed under equipment with leak potential, Repairs to comect any substantial leaks will be completed as socin as possible.

Fueling operations will be performed carefully to prevent inadvertent small releases. All releases will be reported to the Construction Engineer and cleaned up as soon as possible.

Spill control kits will be boatod at the work sitc. Should a spill occur at the construction site, all sefe and practical methots available should be used to prevent material from entering streams or flowing drainage ways. Absorbent pillowes, temporary earth dikes, or other available means should be employed as appropriate, without risking personnel safely. Waste material generated during the cleanup of spills will be managed and disposed of appropriatcly. 


\section{B-8}

\section{SITE INSPECTIONS AND MONITORING}

The project Constinution Engineer will regularty inspect the areas inumediately down gradient and downstream of the site to verify that water quality is not being significantly impacted. Recozd of these inspections and any observations will be maintained in the project file. ORNL OECD Division persommel will periodically inspect the site and verify regulatory compliance, long-term maintenance, and downstrean water quality.

\section{WASTEWATER DISPOSITION}

The Constnuction Engineer will seek advance approval from the ORNL Liquid Waste Certification Oficicer to dispose of all waste water generated as a result of the Waste Evaporator Facility Demolition. Waste wafers requiring approwal include process waters, cooling water, contaminated stormwater. 
Appendix C

ENVIRONMENTAL MANAGEMENT PLAN FOR THE WASTE EVAPORATOR FACILITY DEMOLITION

TASK ORDER PROJECT 


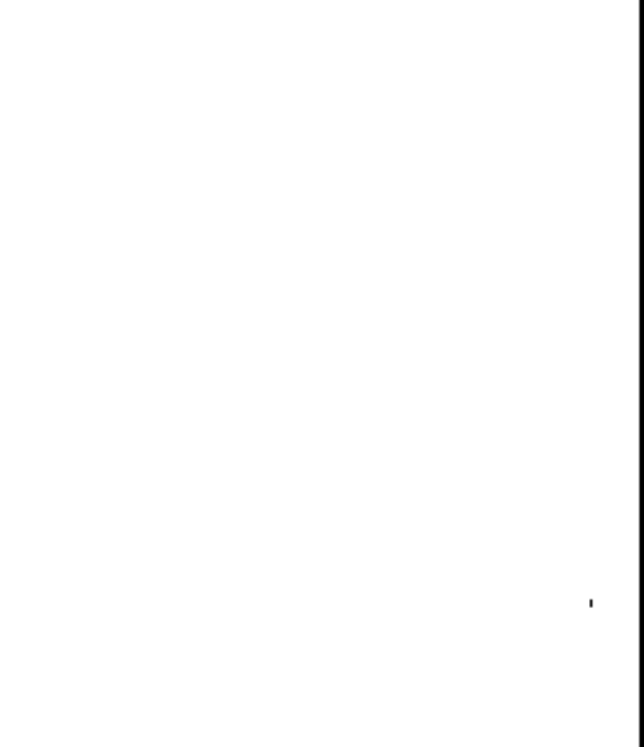


APPROVALS

Environmental Management Plan for the Waste Evaporator Facility Demolition

Task Order Project

Prepared by:

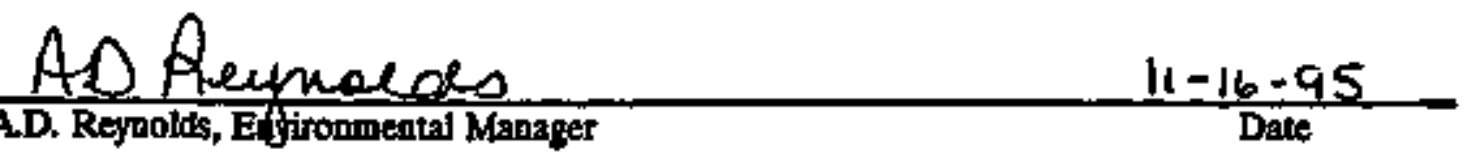

Concurred with:

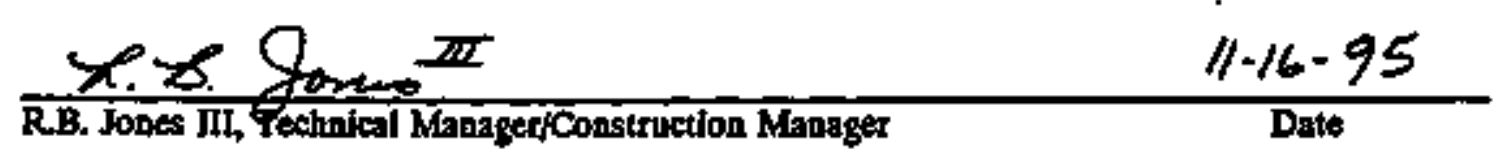

Approved by

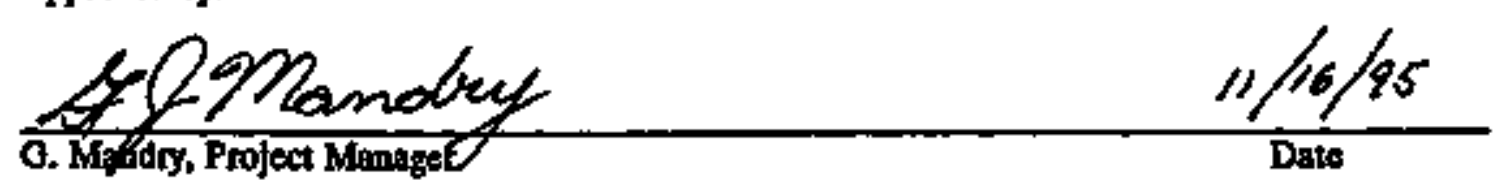




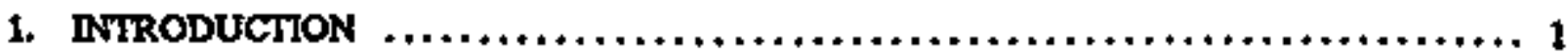

1.1 ENYRONMENTAL, MANAGEMENT PLAN OBJECTTVE $\ldots \ldots \ldots \ldots \ldots \ldots \ldots \ldots \ldots$, $\ldots \ldots$

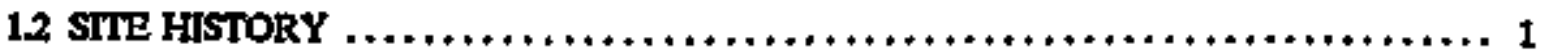

13 PROJECT TECHRICAL OBVCTIVE $\ldots \ldots \ldots \ldots \ldots \ldots \ldots \ldots \ldots \ldots \ldots \ldots \ldots$

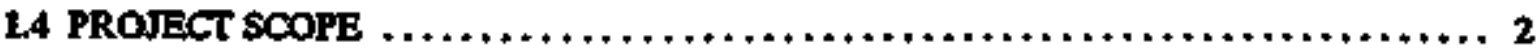

L.4.1 Sire Preparation $\ldots \ldots \ldots \ldots \ldots \ldots \ldots \ldots \ldots \ldots \ldots \ldots \ldots \ldots \ldots \ldots \ldots \ldots \ldots, \ldots \ldots \ldots$

2 REQUTREMENTS $\ldots \ldots \ldots \ldots \ldots \ldots \ldots \ldots \ldots \ldots \ldots \ldots \ldots \ldots \ldots \ldots \ldots \ldots \ldots \ldots \ldots$

2.1 REGULATORY REQUREMENTS $\ldots \ldots \ldots \ldots \ldots \ldots \ldots \ldots \ldots \ldots \ldots \ldots \ldots \ldots$,

21.1 CERCLA Requitrenents:

2.2 NEPA Requirements $\ldots \ldots \ldots \ldots \ldots \ldots \ldots \ldots \ldots \ldots \ldots \ldots \ldots \ldots \ldots \ldots \ldots \ldots$

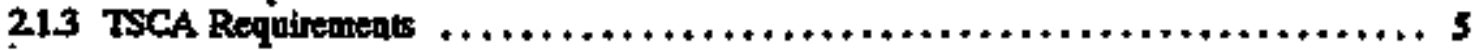

21.4 Clean Water Aat (CWA) Requirements $\ldots \ldots \ldots \ldots \ldots \ldots \ldots \ldots \ldots \ldots \ldots \ldots$. $\ldots \ldots \ldots$

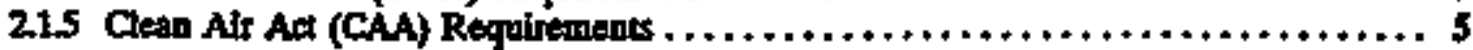

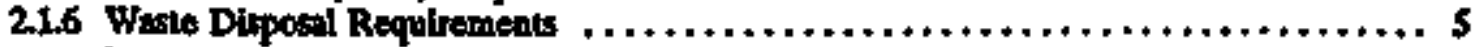

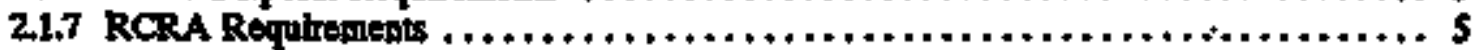

21.8 Asbestos Handling Requirements $\ldots \ldots \ldots \ldots \ldots \ldots \ldots \ldots \ldots \ldots \ldots \ldots \ldots \ldots$

3. OROANIZATIONAL ROLES AND RESPONSIBIITIES $\ldots \ldots \ldots \ldots \ldots \ldots \ldots \ldots \ldots \ldots \ldots$

3.1 ENERGY SYSTENS ENVIRONMENTAL MANAGEMENT DIVISION . . . . . . . . 6

4. REPORTDNG AND RECORDS MANAGEMENT $\ldots \ldots \ldots \ldots \ldots \ldots \ldots \ldots \ldots \ldots \ldots \ldots$

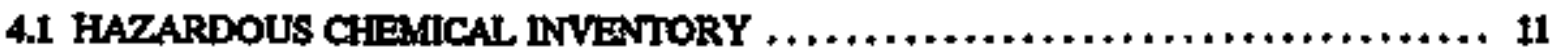

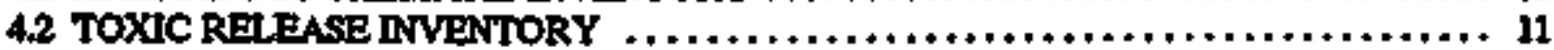

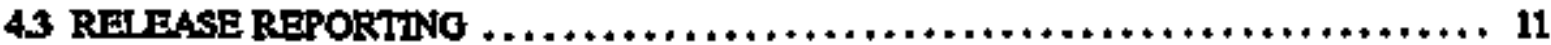

5. COMPLLANCE OVERSIGHT $\ldots \ldots \ldots \ldots \ldots \ldots \ldots \ldots \ldots \ldots \ldots \ldots \ldots \ldots \ldots \ldots \ldots \ldots$ 

ARARs

CAA CERCLA

CWA

D\&D

DOE

DOE-HQ

DOE-ORO

EM

EMD

EPA

FPSC

GAAT

GCO

LLW

NCP

NEPA

NFPA

OECD

ORNL

OSHA

OU

PCB

PCCB

QA

QAPP

RCRA

SolM

SPCC

TBC

TDEC

TSCA

WEF

WMO applicable and relevant or approprlate requizements

Clean Air Aa

Comprehensive Envitonmental Response, Compensation, and Liability Att

Clenn Water Act

Decontamination and Decommissioning

U. S. Department of Enetgy

DOE Headquarters

DOE Oak Rijge Operations

Project Environmental Manager

Environmental Managenept Division

U.S. Environmental Protection AgencyDOE-ORO

fixed price subcontractor

Gunite and Associated Tan's

Project Generator Certification Offrial

low level waste

National Contlngency Plan

National Envirommenlal Policy Act

National Fistoric Preservation Act

Otrice of Envirommental Compliance and Documentation

Oak Ridese National Laboratory

Occupationat Safey and Health Administration

Operable Unit

polychlotidated biphenyl

Profect Change Control Board

quality assorance

Quality Assarance Projext Plan

Resource Conservation and Recovery Act

survellance and maintenance

Spill Prerention Control and Countermeasures Plan

to be considiered"

Tennessec Departmeat of Environmental Compilance

Torlc Substances Control Acl

Waste Evaprorator Fetility

Waste Maragement Organization 



\section{INTRODUCTION}

The misston of the Waste Evaporator Facility (WEF) Decontamination and Decommissinoing (DeD) project is the safe, cost-efiective, and efficient demolition of the facility with emphasts on protecting the eavinonment, the safety and thealth of workers and the generd pubtte.

The following are spectic elements of the project:

- demolition of the above-grade portions of the WEF and using the below-grade portion for containing building robble to the marimum extent possible;

- protection of the environment, the safety and health of wotkers and the general pubtic in the performance of project activities;

- proper managemeat of wastes generated by projea attivites; and

- assurance of quality and cost-effectiveness in the performance of project activities.

\section{ENVIRONLENTAL MANAGEVENT PLAN OBDCTYE}

The purpose of this Emvironmental Management Plan is to elaborate upon the environmental, regulatory, and compliance requitements for the D\&D of the WEF as outlined in the project plan; define roles, responslbilities, and relationships needed to effectively implement reguirements; deine environmenta] managenent oversight aetivities; and establish ervironmental management documentation and reporting requirements.

The projem Envitopmental Management Plan shall not be modified without witten concurrence of the Project and Environmental Managers. Any changes to this Environmental Management Plan will be made in the form of an addendam to the document. The addendum vill be approved by the Project and Environmental Managers.

\subsection{SIIZ FisTORY}

The WEF is located at the Oak Ridge National Laboratory (ORNL). It is sitwated near the intensection of Centrat Avenue and Third Street, on the west slde of the South Tant' Farm.

The WEP was constructed in 1949 and was the first liquid waste evaporator at ORNL. The facility was in Operation from 1949-1954 and received Hqudd low level waste streams from ORNL laboratories and other processing areas for concentration prior to final disposition. Operations vere suspended when the presenty active evaporator factlity (Bullding 2531) was brought ondine. Subsequent instalbations of erperimental equipment wete used to develop fistion-product purification processes and demonstration of contantinated waste incineration.

The facility is a split-level building with approxinate dimensions of $22 \times 28 \times 8 \mathrm{ft}$ high and consists of an operating gallery and a hot cell. The operatiag gallery is a wood structore, expept for the foor and west will, asd contains a craw space under the flow. The hot cell ts a stalintess steel-fined, reinforeed concrete cell which has walls $2 \mathrm{ft}$ thick in the north hall and 3 th thick in the southen balf. The bot cell extends approximately 6 h below-grede. All proves equipment has been remored tom both the openting gallefy and hot cell, except for some enbedoed pipes and a filier housing 
The WEF was accepted isto the Surphus Facilities Management Program in 1976. Periodic surveillance and maintenanoe (S\&M) has been performed since this time. The building strncture is basically sound, although roof repaits were necessitated due to deterioration from rainwater inleakgge. The interior was decontaminated prior to its use as an incinerator facility, resulting in low levels of contamination which are primarily associated with the piping and some surface contamination. The facility is unocrupied and locked, with personnel access only on an occasional basis.

\section{PROJECT TECHNICAL ORIECTVES}

The technicel objective of the WEF deanolition project is to remore the thove-grede portion of the facllity which wonk treilitste continned remedital activities in the South Thent Farn.

The primary project objective of this Comprehensive Environmental Response, Compensation, and Liability Act (CERCLA) Remowal Action is the demolttion of the above-grade portions of the WEF. This action would temove an costacle inhibiling access in the South Tank Farm and would faclitite the continued CERCLA response activities at the Gunite and Associated Tanis (GAAT) Operable Unit (OU). Additional objectives are to remove or reduce the potential health and environmental hazards associated with: (1) the polfchlorinated biphenyl (PCB) and heavy-metal contaminated sediment located to the cell; (2) the mercury contaminated soil under the gallery, and (3) radiation exposure associated with radioactivefy contaminated dust, building sorfaces, debris, and sediments. As building deterioration continues, it is possible that contamination could be transponted off sile through surface water runoff of air dispersal.

The potential tor healtb and safery threats on site and for contaminant releases of site will increase over time if this structure conlirues lo deterlorale. Removal of this structure wovld reduce assoclates ncwipalional bazards. By removing Bullding 3505, unobstructed access to the South Tank Farm for personad and equipment will be possible.

\subsection{PROFECT SCOPE}

The project seope includes the following activities:

- dismantling above-grade portions of the facility to 1-fi below grade (extuding value pits)

- placing bubding concrete in the below-grade portion of the facllity

- temovingjpackaging of mercuryfradtologically-contaminated soil (500 fth)

- removingfpackaging of PCB contaminated sediment (approximately 10 gallons) - mixed waste

- removing of 1500 gallons of raiawater fa cell (based on 1 ft of water in the cell)

- removing non-fitable asbestos (wirdow putty and roofing felt paper)

- removing lead plate - mired waste (1 $\left.\mathbf{t t}^{\mathrm{T}}\right)$

- removing taking lead paint - Resource Conservation and Recovery Act (RCRA) or mited waste, small quanlity

- semoving renaining piptng (below the gallery)

- placing geonembrane over slie, cover with 1 ft of badkfil 
- procuring demolition sabcontractor

- preparing site

- sampling and analyzing for waste characterization and certification

- Iimiled decontamipation (scabbling) - less than $100 \mathrm{ft}^{2}$

- plogging penetrations on exterior walls

- coring drain hole in cell and gallery

- preparingapproval of Health and Safety Plan

- preparinghappsoval of Comprehensive Work Plan

- prepariaghapproval of Hoisting and Rigging Pian

- prepatinglapproval of Trafic Control Plas

- preparing Removal Action Report

- permits

- controlling of boundaries

\subsection{Site Preparation}

\section{A.t.1 Boliking Preparation}

Preparalion of the site will consist of the following activities which will be performed by ORNL prior to the demoltion of the butlding:

- removing materials stored in the gallery portion of the WEF;

- zalocaling the nitrogen line on the south side of the WEF;

- relocatingretoutingprotecting of utility lines and high wohage tines whtch are in close prodimity or are attached to the WEF.

\subsubsection{Builing Demolttion}

Building demolition activities are those items which are detilled in the scope of this project In general, the demoilition of the above-grads structure of the WER, remoral of miscellaneous wastes from the below grade portions, and placement of cousrete slabs in the below-gnade portion of the facility, will comprise the demolition actions to be taken. Any ercess construction debris will be surveyed for tadiological contemination and if found to bo below telease limits, will be properfy packaged, labeled, and transported to the constroution debts landfill by the demolition anteontractor. 


\subsubsection{Projeat Completion}

The project will be considered corrplete when:

- demolition activities are complete;

- site restoration is compleres

- all waste materials have been delivered to Waste Management Organization (WMO); and

- the Removal Action Report is issued.

\section{REQUIREMIENTS}

\section{REOULATORY REQUTREMENTS}

\subsection{CERCLA Requirements}

The princlple regulatory driver for the proposed activity at the WEF is CERCLA. CERCLA specilies compliance with applicable and relerant or appropriate requitements (ARARs) to the erient practicable whetc a removal action is being conducted. Time constratinls, the scope, cost, and duration of the removal action will affect the degree of attafmment of ARARs. Applicable tequirements as defined by the Nationt Contingency Plan (NCP) means those cleanup standards, standards of control, and other substantive Jequirements, criteria, or limitations promulgated under federal environmental or state envitonmental or facility sitting laws that speciflcally address hazartous subsiance, pollutant, wontaminant, remedial action, keation, of other citcumstance lound at a CERCLA site. Only those state standatids that ate ideniffed by a state in 8 tinely manner and that are more stringent than federat requirements may be applicable. Relcrant and approprtate requirements as defined by the NCP means those cleantp stasdards, standards of control, and other substantive requifements, ctiteria, of limitations promolgated under federal environmental or state environmental or facility siuting bers that, while not "applicable" to a hazardous substance, pollutunt, contamiaant, remedial action, localion, or other eircomstance at a CERCLA site, address problems of situations sufficiontly similar to those encountered at the CERCLA sile that their use is well suited to the particular site. Only those state standiards that are jidentified in a timely manner and are more stringett then federal requirements may be relevint and approptiate. ARARs include requirements imposed by RCRA; Toxic Substances Control Act (TSCA); Clean Water Act (CWA); Clean Ait Att (CAA); Nationel Historis Preservation Act (NTPA) and similar state rcgulations. Tennessec regulations including the Air Quality Act, Solid Waste Disposal Act, and Hazardous Waste Manngement Aat may be applicable. U. S. Departient of Energy (DOE) Orders will provide to be considered" (IBC) gulilance The TBC eategory consists of advisorics, criteria, of guldance that were developed by the US. Environmental Protection Agency (EPA), other federal agencies, or states that may be wseful in dexeloping CERCLA remedies.

\subsection{NIEPA Requifrerients}

Since the new Secretarial Policy on the National Environmentril Policy Aat (NEPA) directs DOE to refy on the CERCLA process to oddress NEPA values and public forvolvement procedores, no independent NEPA Ieview of the projed is required. However, in acoordance with the Sectetarinl Policy the project was reviewed for compliance with the ARARs ontline in the Engineering EvaluatlonfCost Avalysis for Building 3506 and found to be in conpliance with the ARARs, as approptiate. This review is documented in the Profect Review Summary for Remowal of Old Waste Evaporator Factilly, Bulteling 3506 (2156X), Issued Augast 24, 1994, and the Letter to Fils for Old Waste Bvaporator Facilty, Building 3506 (2255), issued Febratry 24, 1995. The location-specilic ARAR identified duning the review of the project as seeding attention was that for 
compliance with the Naltonal Historic Preservalion, which was satisfied through the ratification of the Memorandum of Agreement between the U.S. DOE Oak Ridge Operations Office and the Tennessec State Fistoric Preservation Officer submitted to the Advisory Council on Historic Preservation pursuant to 36 CFR 800.5 (c) (4) regarding gunite and associated tank tenedtation and demolition of buikings 3506 and 3515 on the Oak Ridge Reservatjon, Roane County, Tennessee, January 13, 1995.

\section{TSCA Requirements}

Electricas wifing and cable may contain PCBs and witl be stored on pallets by the demolition subcontractor for future pick-up and management by ORNL. Plant \& Equipment Division. Ballasts that bave an unknown concentration of PCBS ate sssiored to have a concentration $\geq 500$ ppin. Batlasts will be sampled prior to finsl disposition in order to determine actual PCB concentrations.

\section{CWA Reyuirement:}

A Site Specific Best Management Praetice has beet developed by ORNL Office of Ebvironmental Compliance and Documentation (OECD). Any changes which might be proposed mast be approved by the Project Environmental Mangaer (EM).

\subsubsection{Spill Provention Control and Conntermeasures Plen (SPCC)}

A SPCC Plan is in place for ORNL. The plan will be furnished to and comptied with by the demolition subcontractor on the WEF Psoject.

\subsection{CAA Requirementa}

Tennessee Department of Environmentpl Compliance (TDEC) ait pollution control regulations and EPA regalations under 40 CFR 61, Subpart $H$ are applicable to this activity. No ongoing procestes or planned activities that result in emisstons to the atmospbere will be conducted as a resalt of this project, therefore permiltiog requirentents ander TDEC role 1200-3-9 will not apply. However, since fugitive emissions could occur when the building is demolished, TDEC rules unier chaples 1200-3-8 would be applicable These mules require that reasonable measores be implemented to miligate the discharge of fugltive particulate matter and liovite visible emisstons. A coptainment tent qill be erected around the facility ptior to demolition activities to minimize the potential for lugilfve enissions. EPA regulations under 40 CFR 61, Subpart H timit radioactive entissions to the atmosphere. In order to determine the applicablity of those regutations, radioattive emisslons must be estimated. The Alr and Spexisl Monitotiog team has been consulted concerning potential radloactive entissions from demolition activites and has determined that 40 CFR 61, Subpart $H$ will not apply.

\section{Wate Dispostil Reguinements}

The Project Tean has propared and anbmitted to WMO a Project Waste Management Plan. The plan Identifies all waste generating activities, their quantitis and the steps taken to mapage the waste properly. This plan was reviewed and approted by WMO prior to the generation of weste. Deviations from the wasts management plin must be approved by the Project Mantger and concurrence by the EM. Alt waste genetated as a result of this project will be characterized and managed accordingly by the ORNL Projet Generator Certilication Ofificial (GCO).

\section{RCRA Roquilrements}

Any hazardons waste geacrated as a resull of this project will be managed by the Project GCO in a staging area in accordance with the substartative requirements of RCRA. A staging area for RCRA hazardous waste 
will be setup pilor to the start of construction activities by the Project and registered with Environmental Management Division (EMD) for the mifred waste.

The GCO managing the hazardous waste staging area will be required to attend:

- Waste Certification Officer-Module 4308, "Managers of Hazardous and Mixed Waste in Satellite and 90 Day Storage Areas, and

- Waste Handlers-Module 4318, "Fazardons Waste Geperator Training"

Records on the harardous waste staging ateas will be maintained by the Project GCO, and copies will be placed in the project files.

\subsection{Solfd Non-Fhritious Waste}

Any solid non-bazardons waste genersied as a result of this project will be managed in a staging area prlor to final disposition.

\section{Radioactive Low Leved Waste}

Any tadioactive low level waste (LLW) generated as a result of this project will be properly managed by the Project GCO. The waste will be appropriately packaged, labeled, and containerized araiting final disposition.

\section{Asbestos Fradiling Requirements}

A Notice of Asbestos Demolition or Renovation was subrnitted to TDEC, 45 days pritot to the start of asbestos demolition. The ORNL Asbestos Management Program will subuth this notiffication.

\section{ORGANIZATIONAL ROIES AND RESPONSIBILTIIES}

\subsection{ROLES AND RESPONSIBILITIES}

The roles and responsibilltes of project members are defined as follows:

Project Mannger - The project mankger will have overall responsiblity for ensuting that this project arcompitishes its mission and objectives. This will include evecution of the project within the schedole and cost criveria as part of this proposal. The project manager's responsibilities will bet

- promoling overall integration of the team members;

- developing the coordinated project phans required to meet objectives and missions;

- completing the project scope within cost and schedule baselines;

- ensuring the compliance of participaris with project ptans and objectivos;

- chatring the Project Change Control Boatd (PCCB);

- approving the distribotion for insoppe changes; 
- establishing and staing the team;

- apptoving all changes to the basetine as established in the PCCB;

- endorsing all other changes before they are submitted to a higher change control board;

- assuring the health and safety of project personnel while performing work

- Assuring exvironmental compliance;

- Lnterfacing wilh DOE and the regulators;

- signing for core team concunfence with the award of subcontraces within the baselire estimate;

- implementing the project's overall Quality Assurance Projeat Plan (QAPP); and

- assisting DOE in regalatory and public interfaces.

Texhnical Manager - The technical manager will be responsible for iategrating the vatious team member's techuical efforts in support of project execotion. The technical manager's specific responsibilitits will be:

- managing projest technical interface with all site support services, operational units, and other project participanis;

- ensoring that technical requirements and constroints are adequately factored into project scope, cost, and schedule;

- overseting fiekd operations to assure health and safery of projed personned;

- participating in the proposal evaluation and recommendation of astard of the demolition subcontractor;

- assuring the development of and compliance whth project planss

- maintaining overall project schedule status;

- ensure proper disposition of all wastes generated;

- ensure the preparation of the Removal Action Report; and

- participating as a member of the PCCB.

Business Manager - The business manager's responsibilities oill bet

- ensoring the integrity, completeness, and timeliness of project cost accounting, funding and authortation control, and work order control;

- providing the project manager with timely and useful management information to sopport decistosa making and control of scope, schedule, and cost, induding appropitiate performanco indicators;

- project reporting

- maintaining the project estimate and scheduite; 
- majntainfing the project baseline; and

- managing the task order project contract activities witb DOE and other procurement actions.

Constraction Marnger . The Construction Manager for the project will be responsible for all construction activities, Including proper disposition of construction waste and materials. The Consinuction Mandger's specific responsibilities includes

- manajing and administering the constroction project;

- planning the construction activities;

- administering construction sthcontracts;

- conducting oversight and survellance of construction field activities to assure compliance with alf applicable environmental regulations;

- particjpating as a member of the PCCB;

- assuring visitor and worker safely and heatth on the project site;

- processing construction field changes;

- monitoring the project baseline and recommending any required actions to the project maniger;

- providing construction, financial, and schedule data to the business manager;

- preparing and sabmitting acddent and occurrence reports for construction-telated events through the DOE system:

- preparing responses to Notice of Volations for construction related exents and submitting to the environmeatal manager,

- assuring development of the project Health and Safety Plan;

- assuring proper dispasition of nonhazardous waste and materials; and

- assuring proper dispositioning of hazrdous waste and materiak generated by the demolttion subcontractor.

Sofety and Fealh Manager - The Safety and Health Manager is responsible for assuring the safety and health of the workers, poblic, and property during construction activities. The manager's duties incinde:

- identifying project hacards and anticipated havards;

- cvaluating the impact of the hazards on the workers, public, and property;

- assuring adherence to the Health and Safety Pian;

- Ifentifying and implementing control measures;

- assoring total complance to Occupational Sefety and Health Administration (OsHA) and applteatite DOE Onder requiremonts; 
- performing accident investigations;

- assuring applicabie reporting and recordkeeping measures are mainiained; and

- providing safety and health oversight and inspections.

Environmental Manager - The Envitonmental Manager will be responsible for overseeing the environmental compliance of the project. Spectific responsibilities include:

- obtaining demolition suhcontractor sighatures on environmental complance documents as aecded;

- developing and fimpieronenting the environmentat compliance strateg;

- Cordinating with the DOE site ofiice, DOE program manager and the regulators to obtain approwis and concurrences;

- dereloping and implementing environmental compliance oversight and inspections;

- maintaining records of all enwironmental inspections:

- serving as the primary project team contact for the environmental regulatory agendes;

- ensuring preparation of all environmontal compliance documentation;

- serving as the primary interface with other plants ond programs on environmental compliance issnes;

- participating as a member of the PCCB; and

- prepating and submitting any Notice Of Vlolation responsts to DOE

Quilty Assumance Managet - The Quslity Assufathoc Manager will be responsible for overseeing the quatity assurance (QA) of the project. Specific responsibilities include

- essure the development of and compliance with the QAPP;

- participating as a member of the PCCB;

- providing oversight of QA related activitites (e\%, profect QA survillance); and

- assuring docoment control and reootds management.

DOE Program Mpmrger - The DOE Program Manager will provide overail projram oversight Specifically, the DOE Program Manager's responsibillites will be:

- funetoning as the primary inierface with the DOE Headquarters (DOE-HO) Program Oifices

- recommending approval of the project baseline and any proposed chinges;

- coordinating and resolving badget isues between DOE Oak Ridge Operations (DOE-ORO) and DOE. HQ:

- providing input to DOE organizations regarding changes to the managing and openting contract; 
- moniroring compliance with environmental, safety, heslth, and QA requirements;

- reporting demolition subcantractor pertormance for payments;

- frviswing and analyzing the estimated cost and schedule for various project participants and elements to ensure that the authorized cost and schedule ate reasonable for the scope of work to be performed;

- analying reports that refect project status, cost and schedule trends, and funding needs.

DOE Project Minaget - The DOE Project Manager will be the primary interface between DOE and the team. The DOE Project Manager's responsibilities include:

- providing DOE project oversight and spectal assistance and fenctioning as an atvisor to the team;

- serving as the liaison, when necessaty, between the ORNL project manager and the DOE Contracting Ofilicer;

- mositoring project cost, schedale, and variances from the otiginalfy established baseline:

- monitoring for adequate and proper implementation of project-refated environmentat, safety, bealoh, and QA requirements defined in the profect plas;

- coordinating the Authorization/Directive System to ensure that fands are available for the authorized seope;

- reviewing and anatyzing the estimated cost and schedvle for project participants and elements to ensure that the autbotized cost and scbedule are reasonobte for the scope of work to be performed;

- tecommending the project baseline and any proposed changes to the DOE program manager for approval;

- participating in project stahus meetings advising on various probtem areas, and assisting in resolution of these problems;

- advising DOE on technical, oost, and scheduling kswes;

- evaluating demoitton subcontractor performance and mating recommendations on fes payment;

- working with the team and coordinating with the DOE-ORO matrix as necessaty;

- analyzing reports on project staks, cost, schodule trends, and Arnding needs;

- monitoring accomplishment of project objectives as tnittilly estabilished or as modified by apptoved changes;

- serving as technicai/cost/schedele advisor to the DOE contracting ofifoer for establithing task order terms and conditions;

- Ecoept the completed anthortzed worts and

- matntainiag the DOE project Gies. 
Regalatory Agencies - Environmental regulatory agencies will maintain their tradjtional, independent oversight of this project. There will be entanced consultation and early planning with

regulatory agencies through the respective ORNL and DOE counterparts authorized to interface with them.

Other Stakefoiders - The team will identify stakeholders for the project and involve them as appropriate in project planning and progress revilow activilies.

\section{REPORTING REQUIREMIENTS}

\section{HAZARDOUS CFEMICAL ENENTORY}

As required by 40 CFR 370, an inventory recotd, including amounts, of all hazardous substances (maleriats that requite an MSDS) will be maintuined by the demolition subcontractor and submitted to the Constrution Manager at the end of the calendar year and at project closeout. The Hazartous Material Information system Office will incorporate the inventory record into the ORNL Site report for submission to regulatory agencles by March 1 of the following yeat.

\section{TOXIC REIRASE NVYNTORY}

As required by 40 CFR 355, an inventory secord, tncluding amonnts, of all toric chemical release data will be maintained by the demolition subconirnctor and submitted to the Consiruction Manager at the end of the calendar year and at project closeont. OECD witl incorporate the inwentory record into the ORNL Site repor for submission to regulatory agencies by July 1 of the following year.

\section{REI BASE REPORTING}

The demoltion subcontractor witl report any release of petroleom produets or hazardous substances inmediately to the Construction Manager, the Facility Manager, or, in thetr absence, the Laborntory Shitt Supervisot.

\section{COMPLANCE OVERSIGHT}

The EM will sscure assessment of peoject activities for compliance with environmental requirements. Observations will be documented in the project reconis and shared with the project team. Appropriats recommendations for improving compliance practioes will be made to the project manager. It is antidpated that more effort will be devoted to assessment at the start and end of demolition activitics. Specifieally, prior to the start of demolition activities, the site will be checked to ensure that all devios and procedores to control fugitive afr emissions, runoff slorm water, petroleum and hapardons substance spills, and wasterater are in place and functional per plans and specifications. Al material and waste staging areas vill also be established prior to the start of demolition. Before the demolition subcontractor demolilizes, the site and secords will be checked to ensore thit the demplition subcontractor has completed all obligations relative to enivironmental compilance. Periodic aseessments will be made by the EM doring demofition; at a minimum the EM will male weekly observations of the site and sctivites. Simpls appropriate checiflists will be developed and osed, based on project requirements, in conjonction with the construction manayet tor conducting assessmenis, Completed checiltsts will become part of the profect record The following assessments schedule will be followed: 


\begin{tabular}{|c|c|c|c|c|}
\hline 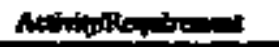 & & 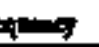 & & Non \\
\hline & 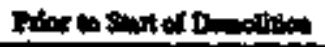 & Weety & Bengintogon & \\
\hline 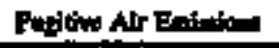 & & $\bullet$ & & 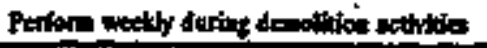 \\
\hline Bbolatar & $\bullet$ & $\bullet$ & - & 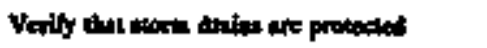 \\
\hline sect & $\bullet$ & $\bullet$ & & 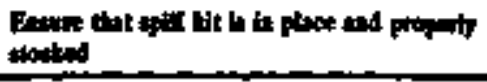 \\
\hline Resu Sadne Am & $\bullet$ & & - & 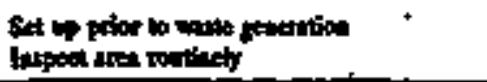 \\
\hline
\end{tabular}




\section{Part II.}

Project Health and Safety Plan for Demolition and Partial Remediation of the Waste Evaporator Facility, Building 3506, at Oak Ridge National Laboratory, Oak Ridge, Tennessee 

APPROVALS

Part II.

Project Health and Safety Plan for Demolition and Partial Remediation of the Waste Evaporator Facility, Building 3506, at Oak Ridge National Laboratory, Oak Ridge, Tennessee
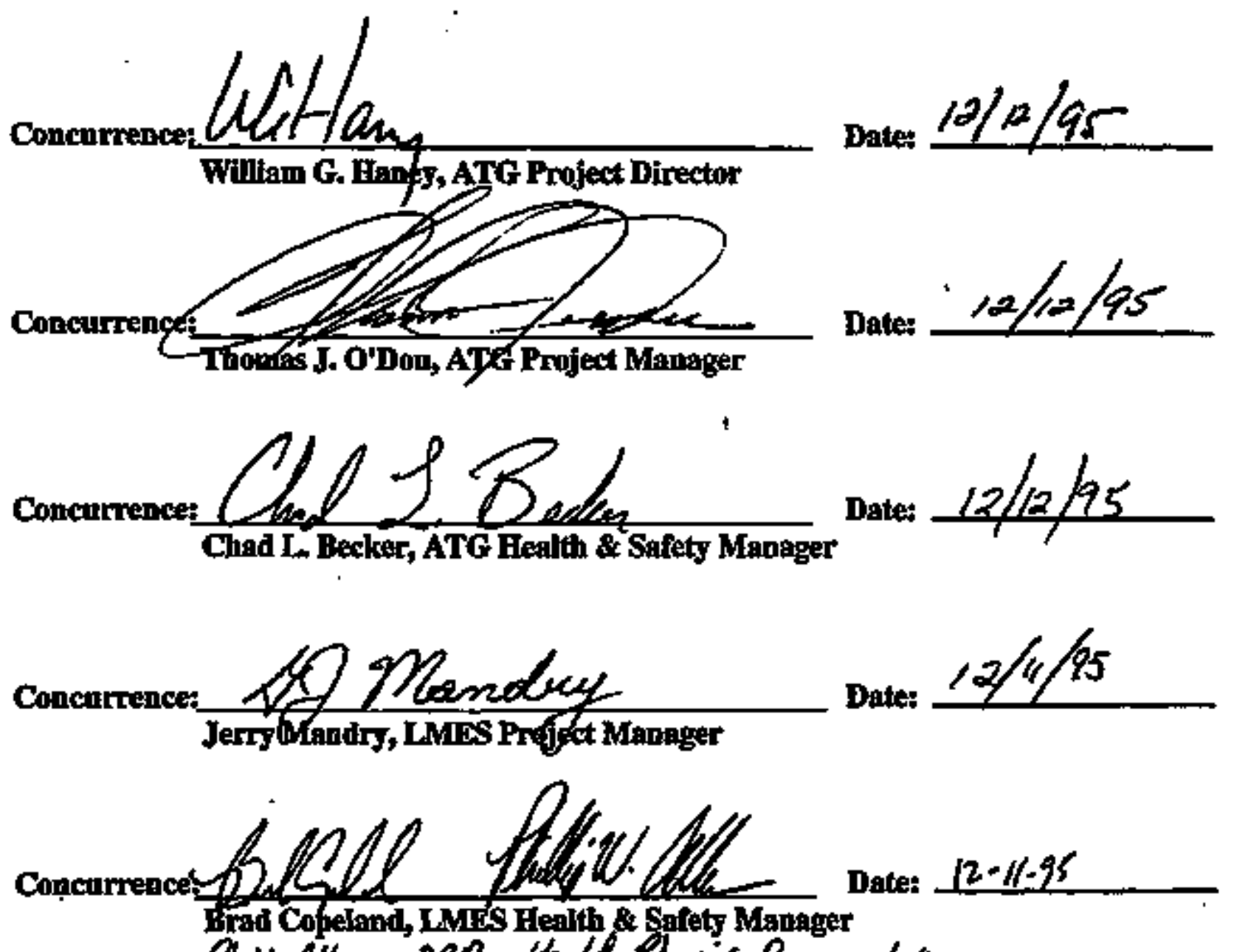
Phil Alts, ORP Heart in Physics Represatabive.

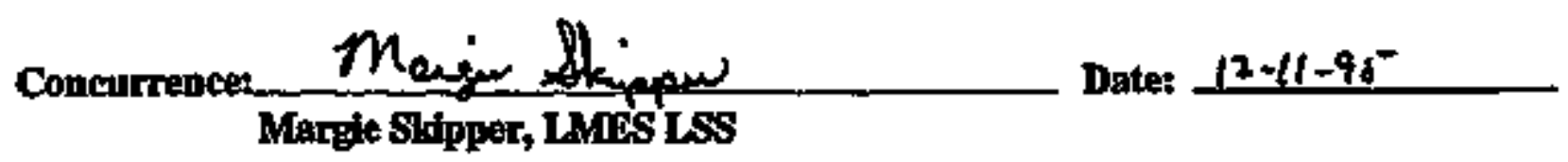





\section{CONTENTS}

1. ENTRODUCTION $\ldots \ldots \ldots \ldots \ldots \ldots, \ldots, \ldots \ldots \ldots \ldots \ldots \ldots \ldots \ldots \ldots \ldots, \quad$ II-5

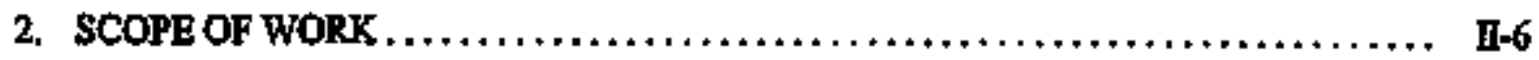

3. HAZARD ASSESSMENT $\ldots \ldots \ldots \ldots \ldots \ldots \ldots \ldots \ldots \ldots \ldots \ldots \ldots \ldots \ldots \ldots, \mathbf{I}-7$

3.1 RADIATION AND HAZARDOUS MATERLALS EXPOSURE $\ldots \ldots \ldots \ldots \ldots \ldots$ II-7

3.2 INDUSTRIAL HAZARDS $\ldots \ldots \ldots \ldots \ldots \ldots \ldots \ldots \ldots \ldots \ldots \ldots \ldots \ldots \ldots$ II-8

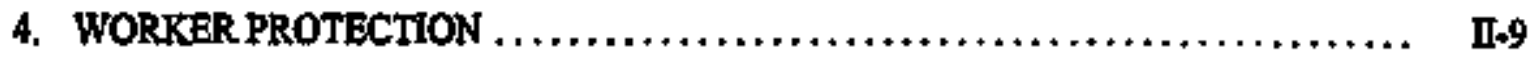

4.1 PERSONKRL PROTECTYON $\ldots \ldots \ldots \ldots \ldots \ldots \ldots \ldots \ldots \ldots \ldots \ldots \ldots$ I-9

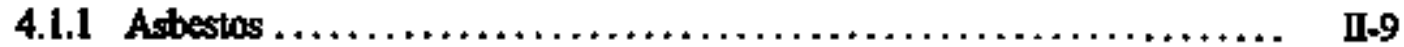

4.1.2 Lead $\ldots \ldots \ldots \ldots \ldots \ldots \ldots \ldots \ldots \ldots \ldots \ldots \ldots \ldots \ldots \ldots \ldots \ldots \ldots \ldots$ II-11

4.1.3 Merany $\ldots \ldots \ldots \ldots \ldots \ldots \ldots \ldots \ldots \ldots \ldots \ldots \ldots \ldots \ldots \ldots \ldots \ldots$ II 12

4.1 .4 Fall Protection $\ldots \ldots \ldots \ldots \ldots \ldots \ldots \ldots \ldots \ldots \ldots \ldots \ldots \ldots \ldots \ldots$, II-12

4.1.5 Personnel Exposure to lonizing Radiation $\ldots \ldots \ldots \ldots \ldots \ldots \ldots \ldots \ldots \ldots$ II-12

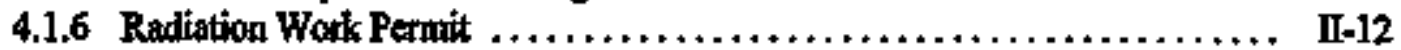

4.1.7 Carcinogen Identification $\ldots \ldots \ldots \ldots \ldots \ldots \ldots \ldots \ldots \ldots \ldots \ldots \ldots \ldots \ldots$ II-12

4.1.8 Respiratory Protection Summary .......................... II-13

4.1 .9 Electrical $\ldots \ldots \ldots \ldots \ldots \ldots \ldots \ldots \ldots \ldots \ldots \ldots \ldots \ldots \ldots \ldots \ldots \ldots \ldots$ II-14

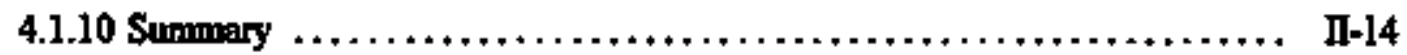

4.2 PERSONNEL MONITORENG $\ldots \ldots \ldots \ldots \ldots \ldots \ldots \ldots \ldots \ldots \ldots \ldots \ldots \ldots$ IIS

4.2.1 Occupational Exposure Guides ............................ II-15

$4,2,2$ Site Registration Form $\ldots \ldots \ldots \ldots \ldots \ldots \ldots \ldots \ldots \ldots \ldots \ldots \ldots \ldots \ldots$ II-15

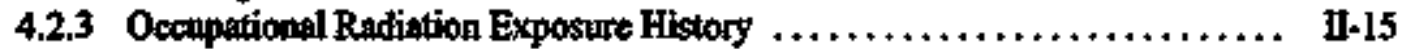

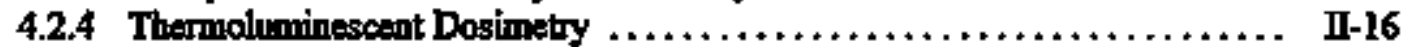

4.2.5 Radiation Work Permits $\ldots \ldots \ldots \ldots \ldots \ldots \ldots \ldots \ldots \ldots \ldots \ldots$ II-16

4.3 TRARNNG $\ldots \ldots \ldots \ldots \ldots \ldots \ldots \ldots \ldots \ldots \ldots \ldots \ldots \ldots \ldots \ldots \ldots \ldots \ldots, \ldots \ldots \ldots$

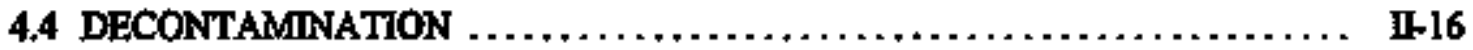

4.4.1 Explanation $\ldots \ldots \ldots \ldots \ldots \ldots \ldots \ldots+\ldots \ldots \ldots \ldots \ldots \ldots+\ldots \ldots \ldots \ldots \ldots$ II-16

4.4.2 Decontamination Methods $\ldots \ldots \ldots \ldots \ldots \ldots \ldots \ldots \ldots \ldots \ldots \ldots$ If 17

5. CONWTRED SPACE $\ldots \ldots \ldots \ldots \ldots \ldots \ldots \ldots \ldots \ldots \ldots \ldots \ldots \ldots \ldots \ldots \ldots \ldots$

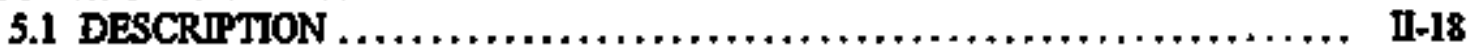

5.1.1 Existing Confined Space $\ldots \ldots \ldots \ldots \ldots \ldots \ldots \ldots \ldots \ldots \ldots \ldots \ldots \ldots$ II-18

5.1 .2 Confined Spece Identification and Permit $\ldots \ldots \ldots \ldots \ldots \ldots \ldots \ldots \ldots$ II-18

5,2 EQUIPMENT $\ldots \ldots \ldots \ldots \ldots \ldots \ldots \ldots \ldots \ldots \ldots \ldots \ldots \ldots \ldots \ldots \ldots$, I 18

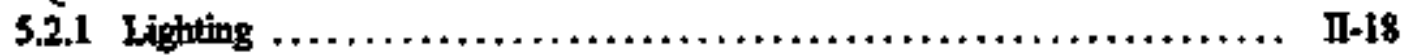

5.2 .2 Tools $\ldots \ldots \ldots \ldots \ldots \ldots \ldots \ldots \ldots \ldots \ldots \ldots \ldots \ldots \ldots \ldots \ldots \ldots$ II-19

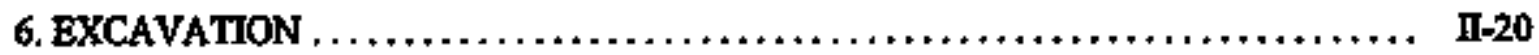

7. HAZARD COMMUNICATION PROGRAM $\ldots \ldots \ldots \ldots \ldots \ldots \ldots \ldots \ldots \ldots \ldots \ldots \ldots \ldots$

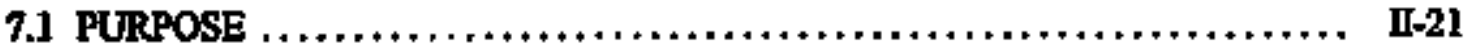

7.2 POLICY $\ldots \ldots \ldots \ldots \ldots \ldots \ldots \ldots \ldots \ldots \ldots \ldots \ldots \ldots \ldots \ldots \ldots \ldots \ldots \ldots$, I-21

7,3 KEY ATG PERSONNEL $\ldots \ldots \ldots \ldots \ldots \ldots \ldots \ldots \ldots \ldots \ldots \ldots \ldots \ldots \ldots$, I-21

7.4 KEY FACILIYY PERSONNEL,$\ldots \ldots \ldots \ldots \ldots \ldots \ldots \ldots \ldots \ldots \ldots \ldots \ldots$, II-2l

7.5 OTHER KEY PERSONNEL $\ldots \ldots \ldots \ldots \ldots \ldots \ldots \ldots \ldots \ldots \ldots \ldots \ldots \ldots$, I-22 
7.6 PROJECT ROLES AND RESPONSIBHITIES $\ldots \ldots \ldots \ldots \ldots \ldots, \ldots, \ldots, \quad \mathbf{I I - 2 2}$

7.6.1 ATG Project Director $\ldots \ldots \ldots \ldots \ldots \ldots \ldots, \ldots, \ldots, \ldots, \ldots, \ldots, \quad \Pi 1-22$

7.6.2 ATG Project Manager $\ldots \ldots \ldots, \ldots, \ldots, \ldots, \ldots \ldots \ldots, \ldots \ldots \ldots, \quad$ H-22

7.6.3 ATG Heakth and Safety Manag $\ldots \ldots \ldots \ldots \ldots \ldots \ldots \ldots \ldots \ldots, \quad \mathbf{1}-22$

7.6 .4 ATG Field Personnel $\ldots \ldots \ldots \ldots \ldots \ldots \ldots \ldots \ldots \ldots \ldots \ldots \ldots \ldots \ldots, \quad$ H-23

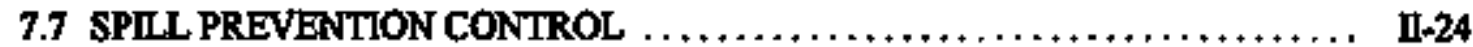

7.8 SITE CONTROL $\ldots \ldots \ldots \ldots \ldots \ldots \ldots \ldots \ldots \ldots \ldots \ldots \ldots \ldots \ldots, \mathbf{I I}-24$

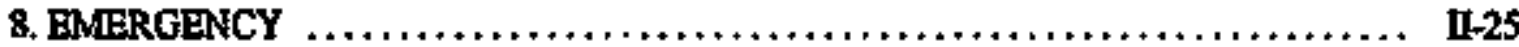

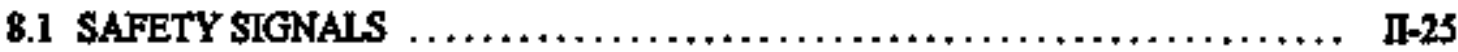

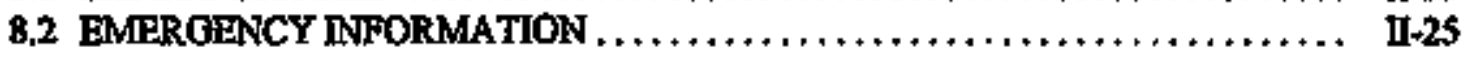

9. TRAFFIC CONTROL $\ldots \ldots \ldots \ldots \ldots \ldots \ldots \ldots \ldots \ldots \ldots \ldots \ldots \ldots \ldots \ldots, \ldots$, II-27

9.1 ROAD CLOSING $\ldots \ldots \ldots \ldots \ldots \ldots \ldots \ldots \ldots \ldots \ldots \ldots \ldots \ldots \ldots, \mathbb{I l}-27$

9.2 NOTIIICATION $\ldots \ldots \ldots \ldots \ldots \ldots \ldots \ldots \ldots \ldots \ldots \ldots \ldots \ldots \ldots$, II 27

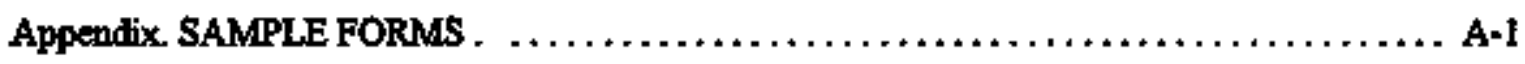




\section{II-5}

\section{INTRODUCTION}

The Allied Technalogy Grop, Inc. (ATG) Project Heallh and Safey Plon incorporates the health and safety procedures and practices to be followet during the activities specified in the ATG Project Work Plon. The ATG Project Health and Safety Plan will bo used to support the project work activities and will be verified with the guidelines specified in the ATG Corporate Health and Sofery Plan. The ATG Project Health and Saftety Plan inchudes radiological, hazardous material taposure, and industrial safety cotcerns. This scope is based on prefiminary assessrnents and potential hazords as identified in tho Stte Charactertzation Report, ORNL/ER/Sub/87-99053/72, (Bechtel 1994) and may be reevaluated or modified to improve efficiency or worker stufety with the concurrence of the ATG Corporate Health Physicist of the Project Director. 


\section{II-6}

\section{SCOPE OF WORK}

Sample collection, monitoring, and work with all radioactive and other hazardous materials will be performed by ATG persomel following the guidelines specified in the ATG Project Work Plan. The tasis associated with this project are detailed in Section 2 of the ATG Work PIon. For the purpose of this contract, all contaminated material wilt be handled with radiological and chemical contamimation controls in place. This project involves mobilization, site setup, radiological and chemical monitoring, decontamination, demolition, and demobilization.

The personal protective equipment (PPE) that will be used on this project will involve three categories at a nimimim Level D. The work tasks will be perfomted by trained and qualified persionnel. Oresight and monitoring will be performed by trained end qualified personnel in excordunce with the ATG Healh and Sojety Plan procedures.

Daily pre-entry briefings will be requined for all personnel prior to work on-site. These briefings will cover wodk to be performed, proper PPE and work practices, health and safety concerns, and any items that the employees need to be made atware of. 


\section{HAZARD ASSESSMENT}

Hazard assessment will be evaluated in two categories: (1) radiation and hazardous materials expoutre, and (2) industrial bazards. Appropriate PPE, monitoring devites and data acquisition will be applied for all hazands.

\subsection{RADIATION AND HAZARDOUS MATERIALS EXPOSURE}

It is expected that an individual performing work on this project will vecive an external cocupational exposure of less than 100 inrem. The pribipal internal hazards are from radionuelides on the wall surfaces inside the hot cell, which are anticipated to be low level concentrations of fission products. Therefore, personnel working with contaminated surfaces and dusts require training in radiological contamination control practices. Proper training, high-efficiency particulate air (HEPA) ventilation, HEPA vacuums, and partial contaimments will be used when necessary to assture that the materials do not becone an internal bazard to the workers or to members of the public. Breathing airborne contaminated dests will be the most likely method of radioactivity entering the body and becoming an internal hamed The airbome concentration of radiomuclises shall be maintained below the acceptable aifrorne contamination conctantration limit of less then $10 \%$ Derived Air Concentration (DAC) in order to assure that the material is not an internal radioactivity hatzard. If $10 \%$ of $1 \mathrm{DAC}$ is anticipated, respiratory protection shall be required.

Extermal exposure to rafiation will come from localized sources which are currently shielded in various areas of the coll. Exposure rates outside the cell will not be significtant to personnel. Howewer, all personel in the job site will be monitored for external exposure to radiation.

Exposere to asbestos will be minimal and it is antioipated that the asbestos at the site is non-friable and entrained in the felt paper of the roof, or within the putty of the window frames. Personinel air sampling will be performed during yemoval to determine potential exposure levels.

Heavy metals are hazards that have been identified on the site. These are currently identified as lead, mercury, and cadimitum.

Exposure to mertury in the soil of the mezzanine will be minimized. Direct reading instruments witl be used to measure levels and appropriate controls will be implemeuted when action levels are approached.

Lead exposure is expected to be minimal duting paint scraping operations and during cutting of concrete blocks which are coated with lead based paint. Lead exposure may result from scabbling operations and in the tot cell during removal of shiejding material around some of the piping penctrations and on the cell wall. Pesonnel air sampling will be performed to determine exposame levels. 


\section{3,2 INDUSTRIAL HAZAROS}

Lifting, suspending, moving and packaging of materinis could cause wear and tear of equipment and fatigne to the workers. Mechanical failure will be reduced by using equipment in near new condition and not overlouding the equipment. The equipment will be visually inspected daily by quslified personnel prior to each use. The site specifics on boisting and rigging will be detailed in the ATG Critical Lff Plon. Safety shoes, hard hats, and safety glasses will be required far personnel working at the site. To minimize the boise exposure, hearing protection will be wom in work areas in close proximity to heavy equipment operation and the diamond wire saw when in operationt.

Physical stress could occur if in individual tries to lift items that are too henvy or oversized Indivitmal lifting linuts skould be fifty ponends maximam Items that are henvy, odd-shaped, or bulky will be lifted by more than one individual or by mechanical mesns. Complications from low ternperature exposits, sucht as frostbile, will be hardled by slowty warming the affected body parts and following up with medical treatment as deemed necessary by the Site Health and Safety Officer. To prevent the dangers of the cold wotk environment, clothes should be layered for maximum hest control. There will also be a heated brenk area for personnel.

Harneds from the use of a dimmond wire saw will include a moving wire which is unshielded Nonessential personnel will not be allowed in close proximity to this operation. The noise associated with this operation will recpuire the use of hearing protection. The hoisting and rigging hazards will be identified in the ATG Critfeal Liff Plan.

The hoisting and rigging on-site witl be in close proximity to a vital communicution fine and a Gunite tank (W-S). The location of equipment will be designated on the mop and caution shatl be used during operutions in this area to prevent damage to com lines and the tank. 


\section{WORKER PROTECTION}

\subsection{PERSONNEL PROTBCTION}

ATG personnel will follow the guidelines stated in the Lockhed Martin Energy Systems (Encrgy Systens) Radiation Work Permit (RWP) and cutlined with this ATG Project Health and Safery

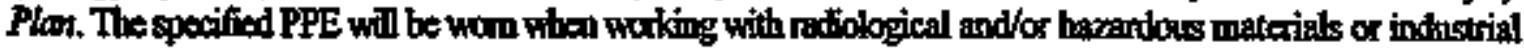
hazank. Direct and passive monitoring will he perfomed to detcmins exposure levels and to torsure a safe

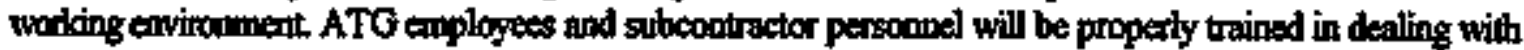
the hamads associated with this project. Only appiowed and inspected tools and equipment will be used by project pessonel.

\subsubsection{Asbestos}

Asbestos is present in the window pulty of the gallery area and in the felt tar of the roof. The window pulty is cracked and flaking but will be removed with the window intact and bagged. The felt is dried and brittle in some spots. The PPE for this phase of the project will be Level C which includes Tywek, full-face air purifying respirator, booties, and gloves. The permissible exposure limit (PEL) for ashestos is 1 ffec per 8-hour time weighted average.

\section{4,1.1.1 Description}

- Roof patching material for the project may contain asbestos.

- Asbostos material is considered nom-fíable in its carrent state.

- Pufty and roofing mastic are considered "intact incidental asbestos-containing roofing material (ACRM)" and work requ' rements shall be in scoordance will Code of Federal Regulattons (CSR), Tile 29, Part 1926,1101, Paragraph (g) (11). Work on the window putty and roofing felt shall be Class II material if the material becomes fijable during demolition.

- Roofing filt shall be Class II material.

- Pefform work in acocalunce with 29 CFR 1926.1101, 40 CFR 763, State of Temessee Regulations,

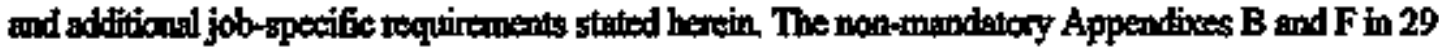
CFR 1926.1101 will be followed for this work.

\subsubsection{Handling}

- Bag asbestos-containing material (ACM) at the immediate removal area, move to a designated cleaning ares within regulated area, and bag again into approwed bags.

- Wrap, label, and seal large pieces of waste materials or building/equipment components containing asbestos with two layers of 6-mil polyethylene sheeting.

- Place asbestos waste mattritil containing sharp-eigod compononls (e.g, nails, serws, tim, streting, chicken wine, etc.) in babeled and approved disposal dnums.

- Vaanm, wat wipe, or wash before removing bags, drms, and wapped material from regulatad area.

- Do not drop or throw to the ground asbestos material or disposal bags. 
- Manually handle, lond, and unload wrapped or bagged waste to prevent rupturing. Unload heavy plastie wrapped waste with fork lifts, crunes, or other suitabls equipment. Suirdy dnums and boxes may be unloaded by slowly raising the truck bed and allowing the contuiners to slide out of the truck. Place waste in the designated waste cell.

\subsubsection{Temporary Storage}

- Cover the ground bekor the double-bugged, wrapped, or drumed waste with 6-mil plastic sheeting.

- Cower the stored waste will 6-tnil plastic sheeting.

- Placo barrier tape of flagging, and asbestos waming signs around stored waste.

- Linit temporary storage to 30 calendar days.

\subsubsection{Vehicle Information}

Identify vehicles used to transport asbestos containing waste mpterial, including transportation fiom regulated areas to temporary slorage locations.

\subsubsection{Material}

- Use caly strfactant or wetting ngents sold for the purpose of asbestos wefting.-Materials intended for other uses, swab as household detergents are not permitted.

- Disposal bags: 6-mil pohyethylene with preptiuted tabels in accordano with Standards 29 CFR 1926.1101 (k)(7)(iii) and 49 CFR 172.

\subsubsection{Equipment}

Equipment having HEPA filter requires testing before on-site use. HEPA filter replacement requires retesting of the equipnient. Perform test in accordance with American Society of Mectuanical Engineers (ASME) N510.

\subsubsection{Communication of Hazards}

In addition to the requirements of $29 C F R$ 1926.1101 (c), the following applies:

Sigas: Sigas shaif be legible at least $20 \mathrm{ft}$ away and confonn to 29 CRR 1910.145 (rod, bbck, and white).

Training Asbestos Awareaess (workers); Asbestos Supervisor (management).

\subsubsection{Methods of Compliance}

Conduct work using state of the at work practices and engineering controls as required in $29 \mathrm{CFR}$ 1926.1101 (g) and Appendix F and perform tasks using the following routines.

- Equip portable hand tools used to drill, cut, or otherwise disturb ACMs with a HEPA-filtered exhmast ventilation. A HEPA-filtered vacuum cleaner, designated for asbestos, can also be used. Position the hose attuchment in such a manuer to ensure dost will be caphured by the vacuum. Adequately wet ACMs with amended water before disturbing or romoving

- Contnim bose ACM as it is removed. Assure anl loose ACM is cortained at tic end of each wark shift. 


\title{
4.1.2 Lead
}

This section provides the requirement for controlling lead and lead containing materials. Using or working with lend materials shall be in accordance with 29 CFR 1926.62. There will be lead abatement in the gallery and the hot cell of the Waste Evaporator Fasility which will include the removal of leadbasod paint chips and the removat of lead shielding plates. The particles of lead-based paint chips will be collected through a HEPA vacum system and properly labeled and disposed. The method of removal will bo with various HEPA-filtered scabblers and needle guns.

The PEL for lead as stated in $29 \mathrm{CFR} 1926.62$ is $50 \mathrm{ug} / \mathrm{m}^{3}$ per 8-hour time weighted average. The action levet is $30 \mathrm{og} / \mathrm{m}^{3}$.

\subsubsection{Medical Surveillance}

ATO will provide a baseline blood test for lead, If the blood lead level mets ar exceeds 50 ug/dl the physician will immediately potify ATG. If two consecutive tests within two weeks meet or exceed $50 \mathrm{vg} / \mathrm{dl}$, then the employee will be medically removed from the project.

ATG will provide persomel ait monitors (PAMs) to the employess involved in remediation for the purpose of determining the initisl aibone concentrations.

If the PEL is exceeded, the employees will bo notitied as well as Energy Systems. There will be constant monitoring of the personnel during kead work areas by PAMs.

\subsubsection{Personal Protective Equipment}

Unxil initial lead levels have been determined, PPE will be Level C. PPE for level C is as follows:

1) Tyvek

\section{LEVELC}

2) Rubber inner-gloves

3) Rubber outer-gloves

4) Full-fare air purifying respirator with GMC.H, or equivalent, cartidg

5) Rubber boots

6) Hard bat

7) Hearing protection if noise is $\geq 85$ decibels

\subsubsection{Training}

ATG will povide docuntented Lead Awatess Trnining to its employees and will have coe Lead Supervisor.

\subsubsection{Labeling}

Lead work inea will be properly labeled as follows:

\author{
WARNING \\ LEAD WORK AREA \\ POISON \\ NO SMOKING OR EATING
}




\subsubsection{Mercury}

No personnel will be allowed to enter the crawlspace during soil removal unless the air is demonstrated to be below the PEL or PPE is used and the project benlth and safely officer is present and has verified the air sample results. The PPE for the mercury abatement will be Level C. This includes as a minimum saranex, booties, hoods, and possibly respiratory protection. Respiratory protection will be at a minimum fill-face wilh Messorb-H or equivalent cartridges. The PEL for Mercury is .05 $\mathrm{mg} / \mathrm{m}^{3}$ per 8-bour time weighted average.

\subsubsection{Fall Protection}

It is anticipated that fall hazards will be encountered during the covise of scheduled tasks. Worker protection requirements will be followed as oufined within Opcupational Safely and Hedth Act of 1970 (OSHA) 29 CFR 1926.104, "Safety Belts, Lifelines, and Lanyards;" and 29 CFR 1926.451, "Seaffolding." Any time there is the possibility for injury due to falls, such as work above $6 \mathrm{ft}$, a solid rail or tether system sihall be present to provide maximum protection for workers. There will also be a seaffolding in place to minimize the fall hazad. The senffolding will be placed inside the hot coll for easy access to the walls which are contaminated. Afl scuffolding will include band rails, kick plates, and locking joints.

\subsection{Personnel Exposure to Ionizing Radiation}

The whole body dose rates from the material in the cell is the primary radiation concern. Dose rates are relatively low with maximum identified dose mates of up to 5 menthour on some surfuces of the hot cell wall, Workers are responsible to minimize fheir dase by using the time of expasure, distance from the soarce, and shielding of the source as effeciently as practical to keep doses "as low as rensonably achievable" (ALARA).

The maximum dose expected to any worker at the job site is less than 100 mrem. This is based on exposine to the maximum wiole body dose rate in the cell of $5 \mathrm{mrem} / \mathrm{hour}$ times 20 hours, and estimate of the duration of decontamination of higher level activity surfaces.

\section{4,1.6 Radiation Work Permit}

The RWP for work at the site will state the personal protective clothing that is to be required to be worn while working in specifie project activities. This RWP will be provided by Energy Systems with if's contemt subject to approval of the ATG Health Physicist. The conttents of the RWP will be considered to be the minimum requirements for the tosk.

\section{4,1.7 Carcinogen Identification}

This section provides the construction requitements for controlling carcinogenic materinls on a project Using or working with carcinogenic materinls shall be in accordance with 29 CFR 1910, Subpart $Z$ and additional requitements stated in this section.

The cancinogertic materinls in question in this section are polychlorinated biphenyls (PCBs) which are in the sludge in the hot cell.

The carcinogenic or suspect carcinogenic material expected to be encourtered on the project have been jdentified as PCBs and asbestos. If existing carcinogenic or suspect carcinogenic mbterial, not 
previously ideatified, is excountered during renovations or demolition axtivities, ATG will immediattely notify Energy Systems. Within ten days, ATG will be given further insinuctions.

\subsubsection{Equipment}

- All vacuum cleaners shall each be equipped with a HEPA filter.

- All sigas shatl be in accordance with 29 CFR 1910, Subpart $Z$ and legible from $20 f t$ away.

- As a minimum, all curcinogen warning signs shall have the following information:

\section{CANCER-SUSPECT AGENT AUTHORIZED PERSONNEL ONLY}

\subsubsection{Genteral Requirements}

- Inmediately notify Energy Systems of spills involving carcinogenic materials.

- Eating, drinking, smoking chewíng gum or tobacco, applying cosmetics, tnking medication, and stcring food is not permitted in regulated areas.

- Hand washing stoll be made available to the workers after haxiting curcinogen material. These facilitie are avaitable to workers at the site.

- ATG will fumish an emergency cye wash which will be located near ench controlled work area when handling carcinogenic material or suspected carcinogenic material.

\subsubsection{Respiratory Protection Summary}

This section provides respiratory requiremitents for constnuction persommel, All ATG personall will be medically qualified to wear a respirator, fit tested, and trained throngh Energy Systems in the proper use of respiratory protection. Description: perform work in accordance with Standard 29 CFR 1926.103 and requirements stated herein.

\subsubsection{Respirators may be required for the following work}

- Welding or cutting existing stnuctures or pipes

- Lond abatement work

- Asbestos abatement

- Scabbling/concrete cutting

- As specifted on the RWP

\section{4,1,8.2 Respirators may additionally be required for the fallowing werk}

- Confined space entry and work

- Handling carcinogen or suspected carcinogenic materia]

- Dust creating activities not adequately controlled 


\subsection{Elentrical}

This sction covers PPE, training, and tool recuivements for working with electrical components. All ATG personnel will rexeive documented Lockout/Tagout training prior to warking on-site. All electrical services will be de-energized by Energy Systens prior to work on the Waste Evaporator Facility as stated in Section 3 of the ATG Project Work Plan.

Appropriats PPE and insulated tools will be utilized by ATG each time any electrical circuit (inchuding those verified as de-energized) is to be aut.

\subsubsection{Personal Protective Equipment}

Rubber insulating glowes, hard hats, rubber matting, and safety glasses. Rubber insulated gloves shall mext the provisions of American Netional Standards lnstimute (ANST)/American Society for Testing and Materialis (ASTM), D 120-1984.

\subsubsection{Tools}

- Metal or conductive badders shall not be used near energized electrical lines or equipment.

- Toots used for culting electrical circuits shall be insulated.

- Electric tools shall either be equipped with a thre-wire cord having the gound wire permaneatly connected to the tool frams and appropriate female receptors/connectors or stall be doubleinsulated and permanently labeled "Double-Insulated," or shall be connected to the power supply by means of an isolating transformer or other isolated power supply.

- Hydraulic and pneumatic tools used on of around energized lines or equipment shall have nonconductive hoses.

- A ground fault interrupter will be present in all electrical circuits.

\subsubsection{Summary}

This section provides on-site safety requirements for culting, hot work, and incidental welding.

\subsubsection{Erecution}

- On-site incidental welding.

- Before welding, buming, or cutting on-site, request and receive an approved Hotwork/Welding Permit. This permit is valid only for the duration noted. Attach the permit to the relding equipment. The oxygen and acetylene tanks will be properly stored in the portable cart and chained to prevent the tamks from tipping over.

- Pefoun welling bining and hotucrk in accoriarce with 29 CFR 1926, Subpart J and ANSI Z 49.1.

- Visnal inspection of the welds is sufficient.

\subsubsection{Protection}

Provide continuous fire watch dring on-site culting, welding, buming, and hot-work operation. Maintin fire watch diring woik breaks, lunch breaks, and 30 minutes after completion of work or after quitting time. Fire watch personmel shall not perform other tasks during the fire watch period. Instruct 
fire watch personnel in accordance with National Fire Protection Association Standard 51B. Provids verifeation of instruetions to Energy Systems. A fire extinguisher will be at euch fire hazord area and exployess will be notified of daity locotions of the work sites.

\subsubsection{Personal Protective Equipment}

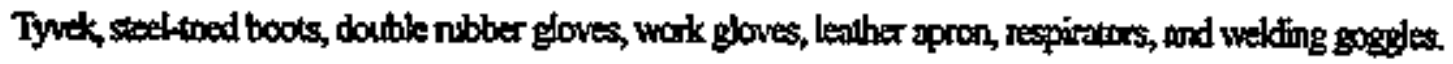

\subsection{PERSONNEL MONITORING}

Occupational exposure hazard(s) will be continually monitored for all personnel on this project. Thermoleminescont dosimeters (TLDs) will be supplied by Enerby Systems. ATG will supply direct and passive monitoring which will be used to identify the hazords. This includes the monitoring of lead, mercury, asbestos, and PCBs. When needed there will also be personnel air monitoring for aisborne contaminants. The direct and passive monitoring equipment will be colibrated before use, after repuir and/or by the munufacturer, as required.

A baseline blood test will be taken to establish a lend ntonitoring program. All contined spaves will be monitored for oxygem, explosive level, and toxic gasts. Alt stumpling will be, reported on ATG surveillantce forms.

\subsubsection{Occupational Radiation Exposure Guides}

ATG Administrative Control Levels per calendar year.

- Whole Body-1.0 Rem

- Extrenities-9.0 Rem

- Skin-3.0 Rem

The ATG Health Physicist and ORNL Radiation Protection shall approve any outhorization for exposure above the control levels. These levels are in agreement with Energy Systems and DOE restrictions for personnel expostures.

\subsubsection{Site Registration Form}

Alt personnel assigned to work on the project of visitors to the project must complece a Site Registration Form, ATG Form 109, prior to starting work. Completed Site Registration Forms will be retained with the personnel exposure files. ATG will imnediately inform the Energy Systems Project Manager in the case of nny skin or clolhing contumination. Any appropriate Entrgy Systems forms may replace ATG forms if all required information is present. Sample forms appear in Appendix A of this ATG Project Health and Sajety Plan.

\subsubsection{Occapational Radiation Exposure History}

Before an ATG individual will be permitted to work in a radiologically controlled area, a U.S. Nuclear Regututory Commission (NRC) Form 4 must be completed and reviewed by the Project Mansger or Site Cocrdintitor. Exposure results shall be listed on the NRC Form 4 on o quarterly basis. 


\subsubsection{Thermoluminescent Dosimetry}

TLDs shall be the permanent recond of an individual's cocupational radiation exposare. The TLDs used by ATG on this job will be provided by Energy Systems. Ail personnel assigned to the project will be issued a TLD for the job or on a monthly basis as the work requines.

In the event of a lost TLD, immediate notification to the Radiation Safety Officer (RSO) or Supervisor is required. A lost TLD report will be completed and filed in the individual's exposure file to ensure proper identification of the dose received when the person was in the area exposed to radiation without monitoring. Notification of the Euergy Systems Radiation Protection Section is required upon discovery of loss and for veplacenent of TLDs.

\subsubsection{Rodiation Work Permits}

All persornel working in the work area must be assigned to a specific RWP applicable to the job being performed. All personnel assigand to a job requiring an RWP shall sign the RWP Sign-In Shet prior to starting work, indicating time in and starting pocket ionization chamber (PIC) dose. Upon corrpletion of the work or at the end of the shift, personnel shall sign out and record the time out and the currint PIC dose.

\subsection{TRAINING}

Individuals assigred to this project will be trained and qualified radjation workers. Training records will be filed as part of the Profect Quality Assurance Report. Training specific to the project will be performed prior to the start of work by the Project Supervisor and recorded on the Training Attendance Record (ATG Form 027) (see sample forms in Appendix A of this plan). Requirements of the Project Work Plan, Project Quality Assurance Plant and the Project Healh and Safoty Plan will be covered in the on-site training. Sampie forms appear in Appendix A of this ATG Profect Health and Safety Plan.

\subsection{DECONTAMINATION}

All persorinel, tooks and equipment will be properly deconkaminated prior to leaving the work area. Proper decontamination will mimimize exposure to employees and preveat conthmination into clean ares. Pescunel will ranowe any disposable PPE and place it in the provided containers prior to leaving the contamination reduction zo:se.

Containment control bartiers will be established and PPE will be required to minimize the potential for areas or personnel to become contaminated. In the event that personnel contamination is detected, the following procebure with be used to remove or contain the contamination.

\subsubsection{Explanation}

This prochere is a follow-ap to the Radiation Survay Procedure which describes how a radiation wouker detects persongl contamination. Once detected this procedure will explain where and bow to decontaninate to acceptabile levels. It firther provides for ongoing documentation to assure adequate review and improvement of existing procedures. 


\subsubsection{Decontamination Methods}

\subsubsection{Persannel Decontamination}

When contanimation is found on the worker, the worker shall immediately notify the Radiation Protection Technician and inform him that he has become contaninated. The worker will indicate where hedshe believes the contamination oucurred, and the route taken to where the surface contamination was detected. This information will assist the Radiation Protection Technician in determining which areas to survey to avoid the contamination of other persomel. After notifying the Radiation Protection Techmician, the indivitual who is contaminated shall, if possible, isolate the contaminated item or items by the use of clean plastic bags and remain in the persontel survey ares. Any method of decontanisation used will require monitoring and documentation of the restilts for each step in the procedute. All liquids used for decontanination purposes, will be considerod contaninated and handled as radiosetive waste. A spray solution of soap and water should be used as the primary agent to remove skin contamination. A soap and water foam will be sprayed on the contaminated brea, allowed to soak for a fow mimutes, then wiped clean, Radiation surveys will be performed between each wash.

NOTE: Under no circumstances vill any individual's skin be abtaded without the presence of a medical doctor. Notify the ATG Corporate Health Physicist, the Director of Decontamintation and Deconamissioning, or the Vice President of Operations immediately, should this in the opinion of the doctor, become necessary.

ATG will immodiatefy inform the Enofy Systems Project Manager if there is any skin or chlothings contamination, as this is a reportable occurrence.

\section{4,4.2.2 Clothing Decontamination}

When contanimation is found on clothing, the worker shall immediately notify the Radiation Protection Technician and inform him of the situation, including where the wooker believes the contmination oceurred and the route taken to where the contamingtion was detected This information will assist the Radiation Protection Technician in determining which areas to survey to avoid the contemination of other personnel. The contaminated clothing shall be removed, taking special care not to furthe contaminate additional clothing or personnel. The item(s) shall be surveged to detemine the degree of contamination. Depending on the sourte of contamination, decontamination methods such as using tape to adhere the contamination to or scraping a shoe with a knife may be used. If the contamingted item cannot be easily deconkaminated without using soap and wate methods, the item shall be disposed of as radioactive waste.

In onder to fully assess the degres of contamination, the skin dose to personind and to critique the

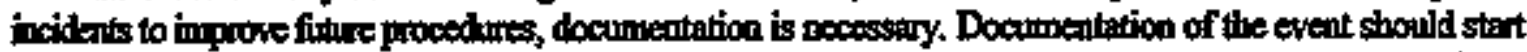
adcontine futm the initial detection of contanination to the final release. Pessomel contaminution will be clasgified in two categories, skin and clotting. A separate form shall be used for each, along wilh a

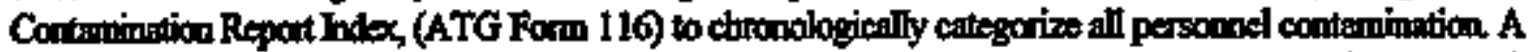
Persomel Contaningtion Repoxt, (ATG Form 117), and a Clothing Contamination Repart, (ATG Form 118) shail be coompleted by the indivitual perfoming the decontamination and sumitted to the Project Manager for evaluation and filing. The Comtamination Report Indes shall be maintained by twe Project RSO. The contemination reports shall be minintined in the individual's exposue file (see sample forms in Appendix A of this ATG Project Weailh and Safery Plant). 


\section{CONFINED SPACE}

A confined space is defined as any enclosed area huving limited means of egress and not intended for bumin oceupancy where ventilation is not adequate to remove toxic or flanmuble atmosphere or axygen deficiency which may exist. Examples of confined spaces are but not timited to: tanks, vessels, bins, boiters, ducts, sewers, underground utility vaults, manholes, pits, tubes, vaults, or vessels. The crawispace of the gallery and the hot cell will require confined space controls. This will be considered Low Risk Confined Space Entry which is defined as: entry into a confined space which is found to have acceptable safety and health cond"tions (i.e., the atmosphere is not considered toxic, flammable, oxygen deficitint, oxygen enriched, and there is no other unaceptable safety or henilti hazards); and there must be an extremely low probability of occurreace for a potential bazard, especially one that could be life threatening Activities that are to be conducted in the space shall be reviewed to determine their impact on the classification of the space.

\subsection{DESCRIPTION}

This section provides constnution repatrements to control access into and work within all confined spaces. Work shall bs in accordance with ANSI "Safety Requirements for Confined Space Standards" Z117,1-1989, OSHA Standards 29 CFR 1926, 29 CFR 1910.146, and addificatal confined space rgoulations.

\subsubsection{Eristing Confined Spaces}

- Low Risk

- Cell Area

- Gallery Crawlspace

\subsubsection{Confined Space Identification and Permit}

Before entry or potentisl earry into a confined space(s), ATG shall complete the first portion of the "Permit Atfachuned fir Confined Space Entry" and submit it to Energy Systems. ATG shell identify all potential confined spaces created by constructioa activities and submit a permit. All excavations over $4 \mathrm{ft}$ in depth shall be considered a potential confined space and require the submittal of a permit.

Before entry into a confined space all applicable monitoring shall be conducted, which includes oxyber, flammability, and toxic gases.

\subsection{EQUIPMENT}

\subsubsection{Lighting}

- Use explasive-proof lighting when the pofential of flamuable vapors or combustible dusts exists. This includes low-roltage lighting.

- Provide a ground-fault circuit intemupter for all 110-V cord-connected lighting. 


\section{III-19}

\subsubsection{Tools}

- Power tools shall be eithes puetumafic or electric.

- Electrical power hand tools shall be protected by a ground-fault circuit interrupter.

- All tools (power or marual) used when the potential for flammable vapors or combustible dusts exists shall be spark proof. 


\section{EXCAVATION}

Excavation will be necessary on this project, but it will be very linited. The major extent of the excavation will take place during the renoval of soil in the erawlspace. All excavations on this project will conform to the specific guidelines established by Energy Systens protocol. 


\section{HAZARD COMMUNICATION PROGRAM}

\subsection{PURPOSE}

The papose of this witten Hacard Communication Program is to comply with the nequinemests of the CFR, Trto 29, Part 1910,1200, "Fazand Condminication" This program is site specific.

\subsection{POLICY}

ATG is an employer engaged in a business within the Standard Industrial Classification Codes 8744, 3829, 1629, and 1799 whers chemicals or hazardous materials are either used or are produced for use. This program will assure that the harards of all chemicals found in the work place will be evaluated and that information concerning their hazard will be transmitted to all affected enployees.

The knowa hazands that will be hardiled on this project will be lead, mercury, PCBs, ashestos, and radioactive material. The hazards have been evaluated in the ATG Project Heolth and Suffry Plan. Commumication to the employes will be handled in the project training and verified through the ATG Project Quality Asstrance Plan. Kentification of the hazards are reguired by posting tho appropriate signs and labeling containers or iterns that contain hazardous materials and/or wastes or radioactive material in accordance with $29 C F R 1910$, and $10 C F R 20$.

Any currently unkown bazards witl be bandled in the same manner when they are enconntered. Material Safety Data Sheots will be distributed and the material will be properly labeled. The Project Health and Safoty Manager will be responsible for conduting the evaluation, communication and ideatification.

All visitors to the site must report to the Project Manager and the Health and Safety Manager. A visitor's $\log$ will be maintained in the site log book The site log book will be kept on-site during operating hours.

\subsection{KEY ATG PERSONNEL}

POSTIION

Program Director

Project Manager

Health \& Safety Menager
NAME

Bill Homey

Tom ODou

Chad Becker
PHONE

482-3275

482-3275

pin 44054

482-3275
PACER

$800719-4431$

$800 / 230.0243$

local 417-8766

\subsection{KEY FACILITY PERSONNEL}

POSTION

Project Manager

Construetion Manager

Heath \& Salety Manager
NAME

G. J. Mindry

R.L. Collins

B. E Copeland
PHONE

576-5557

574-3257

$576-6447$ 
75 OTHER KEY PERSONNEL

$\begin{array}{lll}\text { POSIIION } & \text { NAME } & \text { PHONE } \\ \text { QA.Manager } & \text { W.E. Palmer } & \text { 576-4075 } \\ \text { Busimess Manager } & \text { P.R. Sanders } & 241-2033 \\ \text { Environmental Menager } & \text { A.D. Rejnolds } & 241-3715\end{array}$

\subsection{PROJECT ROLES AND RESPONSIBILITIES}

\section{7,6.1 ATG Project Director}

The Project Director is responsible for the overall project. He is to assure the project mets the objectives and contracted commitments. He has the direct managenent responsibility and authority for cost, schedule, quality and technical performances of all activities in support of the project. He is ultimately responsible for the implementation of all quality related activities. The Radiosetive Waste Remediation Assistant Vice President will serve as Project Director for this project and shall be referred to as such in all doctments from this point forward.

\subsubsection{ATG Project Manager}

The ATG Project Manager will have overall responsibility for ATG's cn-site conduct of the project and will report to the Project Director for oversight and management cottrol. Ho will be the primary point of contsat with the Enery Systems Project Manager. He is responsible for implementing and monitoring compliance with the operations plan and implementing corrective actions. Other responsibilities include; selecting project staff and assigning dutis, reporting to the Project Director project budgets and schedules, and identifying and resolving project specific problems. The Project Manager will assure the tasks are completed in a professional, efirient, and safe manner.

\subsubsection{ATG Health and Sofety Mansiger}

The Health and Safty Manger is specialized in Industrial Hygiene and Occupational Health and Sardy. The Healith and Safety Marager has responsibility for ensuring project activities are conducted according to corporate bealth and stafety policies. He oversees the preparalion of project activities and monitars the project to ensure the ATG Profect Healh and Safery Plan is implemented. He will provide exart advice to project staff when dealing with mexpected health and safety issues encouthtered during the project $H_{0}$ is the primery on-site contact for safety and health during field activities. The Health and Safety Menager overses the on-site exemution of all field activities regarding safety and health procedures. He hes the andhority to stop all wonk if conditions ane judged to be havardous to on-site pessonnel, to the public, or to the environment The Hea'th and Safety Manager will remain at the project site at all times while wodkers are performing site activities. Other specific responsibilities are as follows:

1. Ensures that all on-site pnoject personnel meet the required kevel of training, medical requirentents including respirator fit test (as required), attend a pre-entry briofing on project and potential sitc hazards, and reviow the ATG Project Work Plan and Profect Healh ond Safery Plan. Mantains copies of docamentation of the above at the project site and ensures documentation is available for on-site review. Note: the ORNL Special Access Training Badige may be used as verification of training.

2. Require persomel to obtain immediate modical attention in the case of a work-rekted ijiny or illinss. 
3. Deny access to all or any portion of the work area as warranted.

4. Order work to cease, evacuntion of the work area by all personel, and resstablish safe working conditions, as noeded. Contact the Laboratory Shift Superintendent's (LSS) Ofice when stop work conditions exist due to suspected health and safety hazard(s).

5. Control access to the site by visitors and uzauthorized personnel, Advise visitors and unauthorized personmel of their nespansibilities, and ensure they meet acoess requirements before entry into the contamination rectuction zone of exclusion zone is allowed.

6. Enswre the comeat field excution of the ATG Project Work Plom and Project Health and Safety Plom.

7. Ensure this ATG Project Work Phas and Project Health and Sofety Plon are revised and approved if there are changes in site conditions or tasks.

8. Advise emergency response personnel in an emergency.

9. Coordinate with the Safety and Heath Evaluation and Support Team (SHEST) and Radiation Protection (RP) to establish site work zones, and the level of reguired personnel protection, monitoring, and other controls.

10. Coordinate and minimize the number of personel and amount of equipment in the work zones.

1I. Cocrdinate accident prevention by oversight of field activities and being aware of all sits operations.

12. Ensure that needed work permits are obtained and made available on site.

13. Ensume that the Hazardous Waste Operations and Emergency Response (HAZWOPER) Program Coordinator (HPC), SHEST, and RP are contatted prior to commenoement of site work to: (1) notify of intent to begin work, and (2) schedmle monitoring support, as needed.

14. Condunt daily inspection of the work site.

15. Provide the HPC a list of personmed participating in site activities to deternine the need for inclusioa in the hazardous waste worker medical surveillance program.

16. Ensures that appropriate fall protection measures are in place, as warmed.

17. Ensures that an approved hoisting and rigging plan is avaitable, as warranted.

18. Ensure that appropriate measure have been taken to prevent spills.

\subsubsection{ATG Field Personnel}

ATG Field Personnel will take all reasonable precartions to prevent injury to themselves and to their fellow workens by remaining alert to potential hamful sitalations. All tasks must be performed in accordance with the ATG Project Work Plan and the Project Healh and Safety Plon. Any unsafe conditions must be reported immodiately to the Project Manager and/or the Heallt and Safety Manager. Personed mast roport any modical conditions that may be affected by the work environnent. All injuries 
must be reported-no mafter bow minor. The Field Persomat must read and comply with all postings and rules at the work site. Spilling and splasting of materials must be kept to a minimum. Good housekeping must be maintained within and arouad the work area.

\subsection{SPLL PREVENTION CONIROL}

Spill prevention control shall be as follows:

- Secondary nuroff will be controlled as described in Section 3.11 of the Resources Conservation and Recovery Act (RCRA) Factlities Closure Work Plan.

- Decontangination pads (ff requined) will be constructed to contain all free liquids as described in Section 3,6 of the RCRA Facilities Closture Work Plan.

- All work on site will proceed tocording to the ORNL Spill Prewention Control and Countermeasures Plon.

\subsection{STTE CONTROL}

Work zones with be established to prevent unathorized entry and to prevent any contamination outside the work site. Three zones will be established to determine work areas and control the flow of persomel into these areas. The 20nes will consist of en exclusion zone, contamination reduction zope, and a support zone. The zones will be clearly makked and will change periodically as the project progresses. The barriers will be property posted for any radiological, hazardous material, or industrial hazards.

Entrance and exit aress will becleaty marked. Periodic monitoring of the zanes will be performed to ensure postiogs and bariers are in place.

Visitors to the work areas must be cleared by the Project Manager and fill in a "Visitor Sign-hn Shest" Before entry into the work areas, visitors must be provided with the proper PPE and wom to the approwal of ths Health and Safety Manager.

Personnel in the work area will be required to use the buddy system. Personnel will maintain intemal commmication, line-of-sight with other workers, and work party monitoting. A two-way radio will be maintained in the support zone for emergency communications. 


\section{EMERGENCY}

\subsection{SAFETY SIGNALS}

Vehick, tractor, and partable gas-operated horns are used for safety signals as follows:

One Long Blast-WARNING ALARM—Prepare for Emergency Response.

\subsection{EMERGENCY INFORMATION}

The responsibility of day-to-day implementation of this information primarily lies with the Health and Safty Manager. During an actual emagency response situation, the Health and Safoty Manager will serve as the Emergency Coordinator until the LSS or energency response team arrives.

Medical assistance will be provided by either the Health Division with a doctor and murse, or the Protective Services Organization with Erangency Medical Technicians. The LSS will provide ernigency response persoumel and coordinate entergency assistance. The radio mumber for the LSS is Station 103. The telephone number for the LS is 5746606, In thent the LSS is not available, anergency services may be reached at the telephoies nurobers listed on the following page.

The Health and Safety Manager will perform the following pre-emergency response with the LSS:

1. Locate nearest telephone and alam station.

2. Confirm and post energency telephone numbers.

3. Post site map of work areas marked with evacuation routes.

4. Inventory and check out on-site emergency equipment and supplies, as warranted.

In the event of an energency that requires evacuation of the site, a verbal instnuction will be given by the Health and Safety Manager that will secount for all persconel, ascertsin information about the emergency, and advise further instruetions to the on-site personeal. In all sibsations that require evacuation, personnel shall not roenter the work are until the conditions causing the emergency have been conrected, the hazrod reassessed, the ATG Project Work Plan and Project Health and Sofety Plan nevised, appnoved, and reviewed with on-site personenel, and instructions given for reentry. Reentry will not be allowed until approved by the LSS, who serves as the Laboratory Emergency Director.

The Fealdh and Safety Manager will brief workers on emergency response procedurts and the evacuation route in the pre-entry briefing. 
EMERGENCY PHONE NUMBERS

\begin{tabular}{|c|c|c|}
\hline Bangency Permonel & Paoue \# & Radlo * \\
\hline $\begin{array}{l}\text { ORNL Draectency Response } \\
\text { Laboratory Shit Superintendent } \\
\text { Firo Department } \\
\text { Medical Center } \\
\text { Security } \\
\text { SHEST }\end{array}$ & $\begin{array}{l}911 \\
574-6606 \\
574-5678 \\
574-7431 \\
574-6646 \\
574-6447\end{array}$ & $\begin{array}{l}294 \\
294 \\
294 \\
294 \\
294 \\
231\end{array}$ \\
\hline $\begin{array}{l}\text { Restiation Protection } \\
\text { Environenental Complimen }\end{array}$ & $574-8770$ & 216 \\
\hline
\end{tabular}

The nearest hospital is Methodist Medical Center, which is 12 miles northeast of the site on Highway 95. 


\section{TRAFFIC CONTROL PLAN}

The decontamination and decommissioning of Buildint 3506 will require a traffic control plan designed to describe the rerouting of traffic due to work. The work at Building 3506 may cause temporary closing af Third Street at the work site. This will only be temporary for movement of heavy equipinent and shipment of wastes. The closing of this will follow standard Tennessee Department of Transportation closing procedures. These procedures will be modiffed to eccommodats Energy Systems operations with minimal closme time. There will not be any closure of pedestrian walkways under noted cixcunstances for vehicular traffic.

\subsection{ROAD CLOSING}

Clasing of Thind Strect will be done by placing highly visible markers and bartels or cones across the strect. An alternate roufe will be posted when needed. This aiternate route will move traffic to Fourth Street temporarily to facilitate movement of vehicles around the site at Building 3506.

\subsection{NOTIHCATION}

The Energy Systems Constnuction Engineer will be notified within twenty-four hours af any pending road closures pertaining to Building 3506 prior to achual closing of the road All rerouting of traflic will be coordinated with Energy Systems to minimize delays of operations. 

Appendix

SAMPLE FORMS 


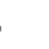

$-$ 


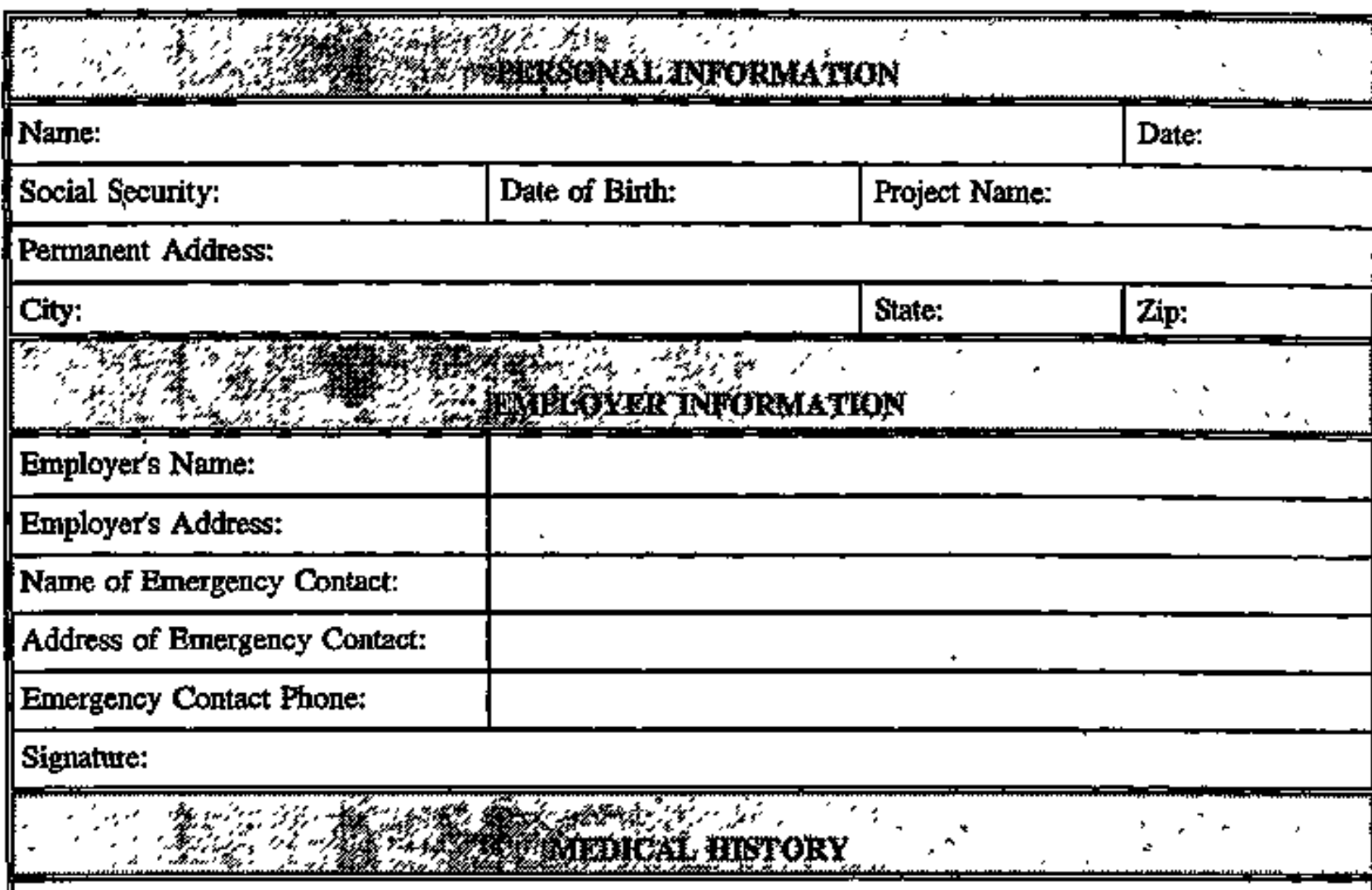

List any condition or ailment that may affect your ability to perform your job:

Indicate if you are epileptic or diabetic:

List any allergies you have:

List any medications you are now taking:

Last Tetanus Shot date:

Date of Last Physical:

Signature:

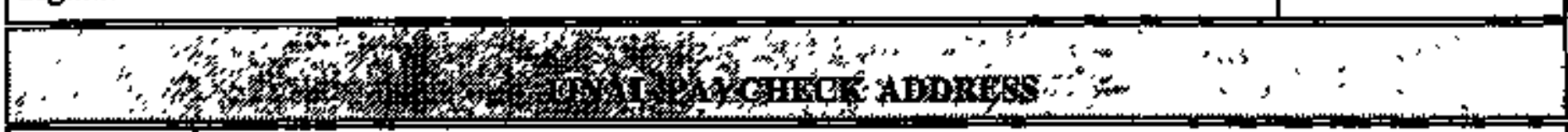

Address:

City:

Phone:

fedrat

ALLIED TECHNOLOGY GROUP, INC. FORM ATGF-109 03/95 

TRAINING RECORD

TRAINING DATE:

INSTRUCTOR:

LOCATION:

TOTAL CLASS HOURS:

TRAINING COURSE TITLE:

SCOPE OF TRAINING:

NAME OF STUDENT

SOCIAL SECURITY NO.

SIGNATURE

ב

TRANING APPROVED BY (Project Director):

ALLIED TECHNOLOGY GROUP, INC - FORM 027 



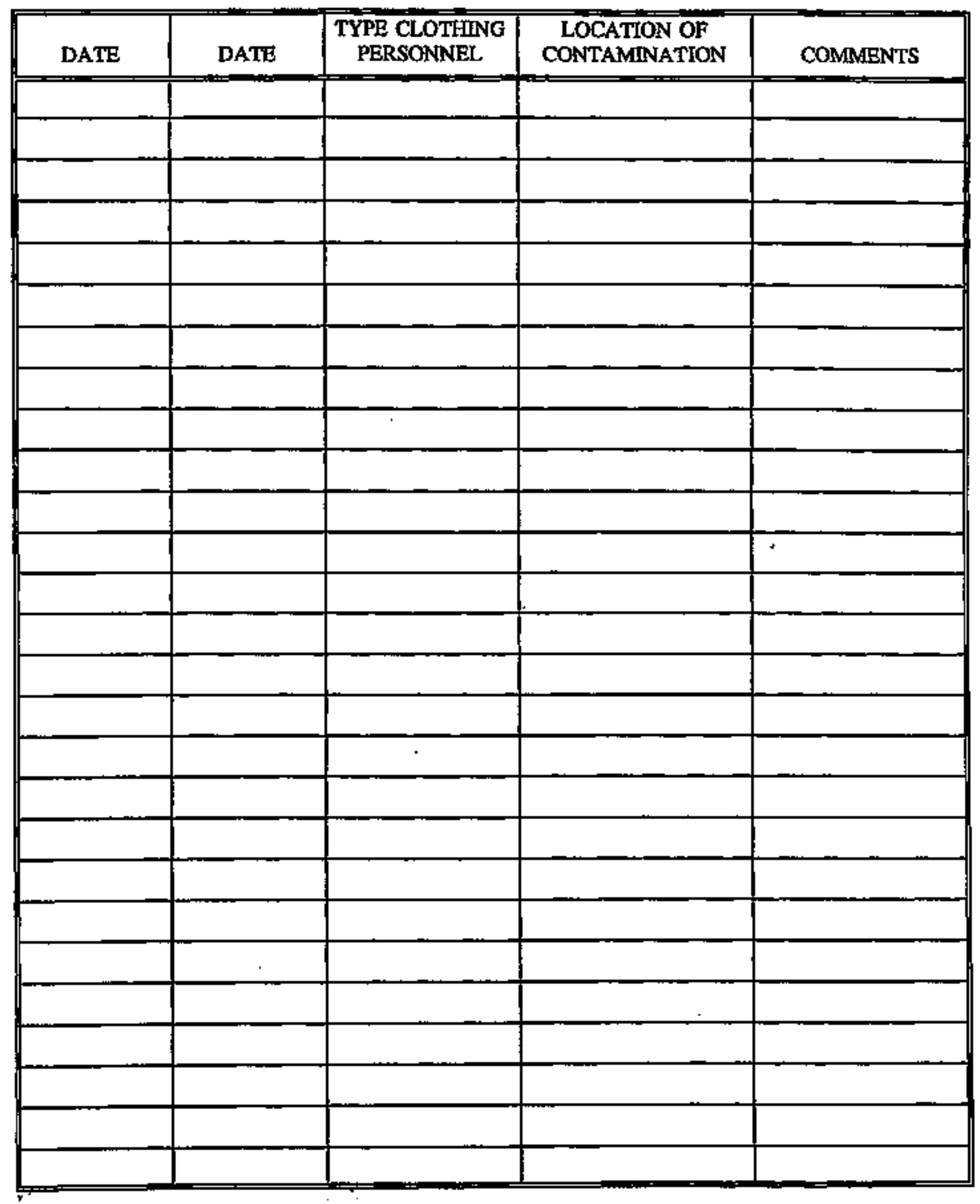

ALLIED TECHNOLOGY GROUP, INC. - FORM 116 



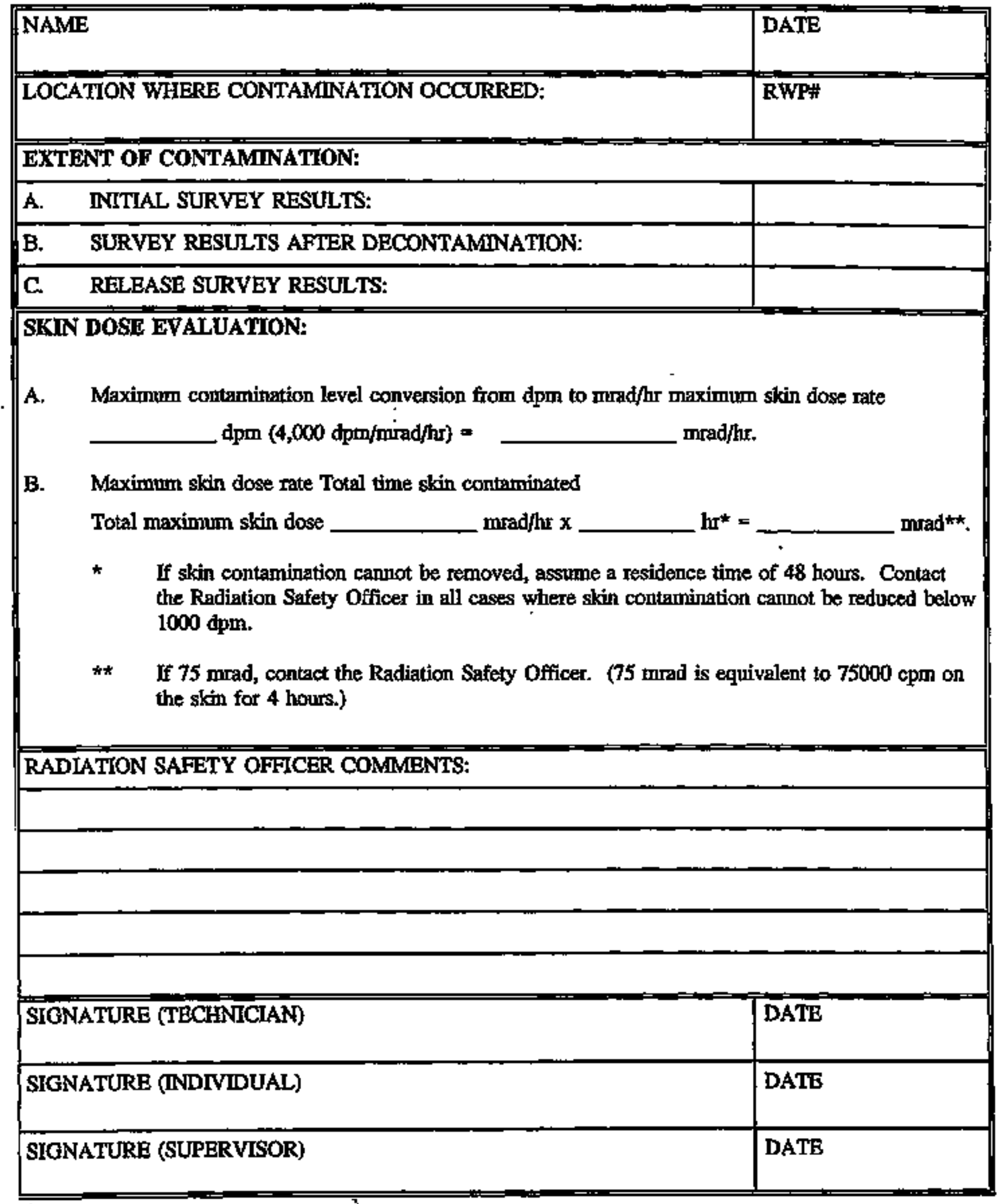

ALLIED TECHNOLOGY GROUP, INC. - FORM 117 


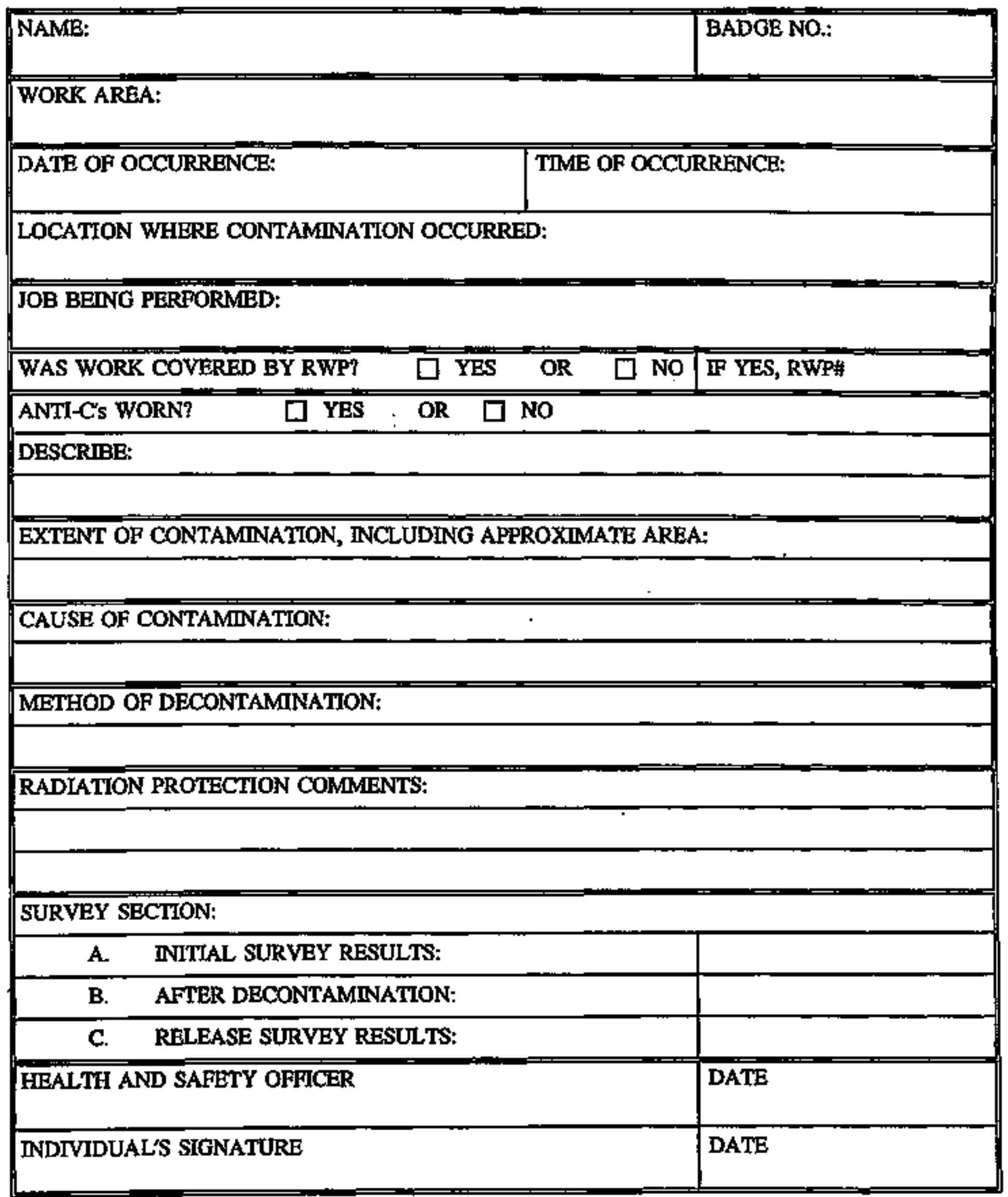

ALLIED TECHNOLOGY GROUP, INC. - FORM 118 
(2) 


\section{REFERENCES}

(Bechtel 1994). Bechtel National, lec. Site Characterization Report for Building 3506 at Oak Ridge Nattonal Laboratory, Oak Ridge, Tennessee. (ORNL/ER/Sub/87-99053/72). July 1994.

(Energy Systens 1995a). Lockheed Martin Energy Systems, Inc. Service Contract Speciflcattons for Decontomination and Demolition of Bulding 3506. Project Onder No. 9440020.01, "Decontanination and Demolition of Buildiung 3506 at Oak Ridge National Laboratory." August 1, 1995.

(Energy Systems 1995b). Lockhoed Martin Energy Systems, Inc. "Request for Proposal" No. KEP03-18. Angust 8, 1995.

(DOE). U.S. Department of Energy. Table IV-1, "Surface Contamination Limits" Order 5400.5.

(Energy Systems). Health, Safety, and Dawrommental Profection Procedure for Eactaration Operattons, M-116, "Radiological Soil Haniling Criteria." 



\section{DISTRIBUTION}

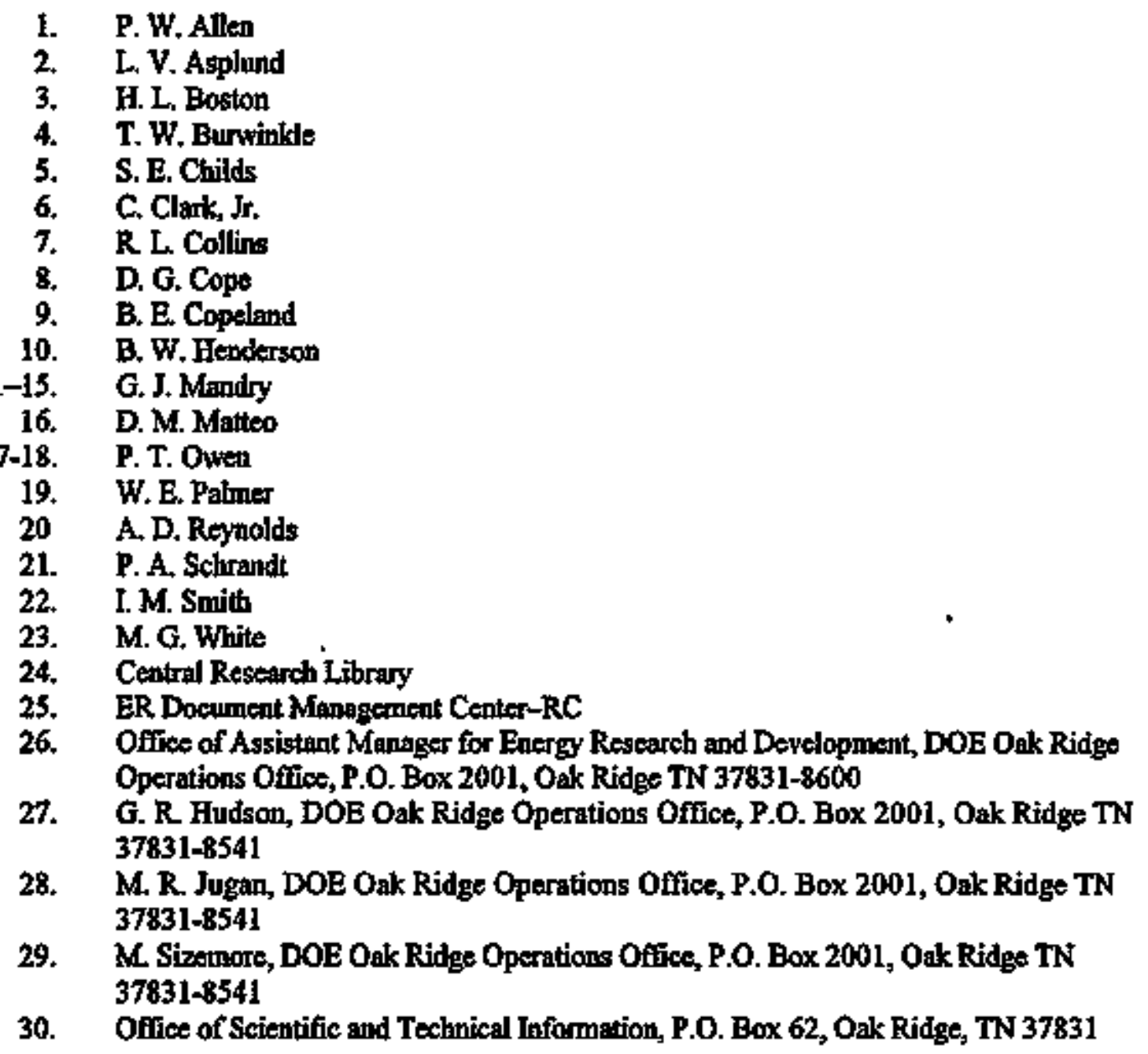


